GUERRA, Rodrigo, "Impulso irresistible en el miedo insuperable"

Polit. Crim. Vol. 14, No 28 (Diciembre 2019), Art. 2, pp. 54-94.

[http://politcrim.com/wp-content/uploads/2019/10/Vol14N28A2.pdf]

\title{
Impulso irresistible en el miedo insuperable
}

\section{Irresistible impulse within unbeatable fear}

\author{
Rodrigo Guerra Espinosa* \\ Profesor de Derecho Penal de la Universidad de los Andes, Chile \\ rguerra@uandes.cl
}

\section{Resumen}

El artículo presenta un análisis en torno a la eximente de miedo insuperable en el Derecho penal chileno. A partir del concepto dogmático de impulso irresistible y el análisis de diferentes trastornos mentales en la jurisprudencia chilena, el artículo presenta una reconstrucción racional del miedo insuperable que rechaza su relación con males imaginarios. Por ello, el objetivo de este artículo es demostrar que el miedo insuperable conlleva el análisis de trastorno mental que no altera el juicio de la realidad. Luego, tratar las consecuencias que siguen a esta interpretación en el estado de necesidad y, asimismo, entregar una propuesta de diferenciación entre acto perceptivo e imaginario en casos de miedo insuperable.

\section{Palabras clave}

Impulso irresistible, miedo insuperable, trastornos mentales

\begin{abstract}
The article provides a rational reconstruction of the unbeatable fear excuse under the Chilean criminal law system. This objective is developed based on the verification of a special treatment that Chilean jurisprudence gives to this criminal excuse, according to two special normative elements: irresistible impulses and mental disorders. This rational reconstruction only allows real evils in the unbeatable fear excuse. For this reason, the central objective is to demonstrate how the unbeatable fear excuse only recognizes mental disorder that does not affect the agent reality judgment. Also, this article analyzes the effects of this doctrinal interpretation. Thus, according to the necessity defense and the recognition of a certain type of mental disorders under the unbeatable fear excuse. Finally, this article tries to make a dogmatic differentiation between perceptive and imaginary acts under the unbeatable fear cases.
\end{abstract}

\section{Key words}

Irresistible impulse, unbeatable fear, mental disorders

\footnotetext{
* Agradezco los valiosos comentarios efectuados por el psiquiatra chileno Cesar Ojeda Figueroa.
} 


\section{Introducción}

Una las características más interesantes del miedo insuperable se encuentra en el concepto de impulso irresistible y su forma de graduación. De acuerdo con esta, el miedo insuperable requiere jurídicamente, para constituirse como una eximente, de una perturbación en el agente y la presencia de un peligro o agresión ilegítima. Estas exigencias no difieren de las que se observan en una parte de la doctrina española, y de los consensos alcanzados en el Código Penal tipo para Latinoamérica. ${ }^{1}$ Con ello, el sistema del Código Penal chileno reconocería la existencia de estos elementos en el miedo insuperable, los que serían un distintivo respecto de lo que exige el estado de necesidad o la legítima defensa. Asimismo, el Código Penal chileno asigna un espacio a la eximente del miedo insuperable en el art. 10 $\mathrm{N}^{\circ} 9$, y no la relaciona directamente con situaciones de exceso en la legítima defensa. ${ }^{2} \mathrm{El}$ miedo insuperable tendría un elemento característico que no presentaría esta última eximente.

Sin embargo, la diferencia entre el estado de necesidad y la legítima defensa con el miedo insuperable, se observa en el reconocimiento, en este último caso, de males o peligros imaginarios. La razón de la diferencia se encuentra en solo reconocer peligros reales en el miedo insuperable - como lo exigía hace tiempo un sector de la doctrina española - ante la existencia de un grado de perturbación en la persona que si bien no conlleva un trastorno del juicio de la realidad, respondería a situaciones en las que es posible demostrar la presencia de males imaginarios. Esta interpretación alteraría la función de la eximente, porque el agente, en el miedo insuperable, puede diferenciar entre acto perceptivo e imaginario, es decir, el agente no estaría condicionado por una alteración del juicio de la realidad; en una superposición patológica entre acto perceptivo e imaginario propia del delirio. Así, nos parece que el concepto de "pérdida de contacto con la realidad...parece suficientemente sencillo como para servir, al menos, de idea rectora en esta cuestión".

El objeto de este artículo es presentar una reinterpretación del miedo insuperable que dé cuenta de su tratamiento en el sistema penal chileno y reconozca la situación en que se encuentra. A ese respecto, contra una parte de la doctrina, sostendremos que es admisible

\footnotetext{
${ }^{1}$ La comisión chilena que participó en el proyecto de elaboración del Código penal tipo para Latinoamérica se mostró conteste en diferenciar el miedo insuperable del estado de necesidad, porque en la primera eximente concurre una perturbación anímica que incide en el comportamiento del agente. La Comisión chilena sostuvo en dicho Proyecto que el miedo insuperable se provoca por razones totalmente diferentes a las de un estado de necesidad exculpante, véase INSTITUTO DE CIENCIAS PENALES, Proyecto de Código Penal Tipo para Iberoamérica. Antecedentes, plan de trabajo, documentos preparatorios, Santiago (Chile): Universitaria, 1963, pp. 1 y 8; MATUS ACUÑA, Jean Pierre, "La doctrina penal de la (fallida) recodificación chilena del Siglo XX y principios del XXI", Revista Política Criminal, vol. 5, № 9 (2010), pp. 143 - 206, p. 186. En esta línea, respecto del desarrollo histórico de la trama del miedo insuperable y el estado de necesidad en Chile, en atención a las primeras secciones de este artículo, véase GUERRA ESPINOSA, Rodrigo, Estado de necesidad como conflicto de intereses: una interpretación: una propuesta de interpretación desde la inevitabilidad, Santiago (Chile): Ara Editores, 2017, pp. 21 - 218.

${ }^{2}$ En este contexto, el parágrafo 33 del StGB o Código penal alemán dispone: Exceso en la legítima defensa. Si el autor excede los límites de la legítima defensa por confusión temor o miedo, entonces no será castigado, véase LÓPEZ DÍAZ, Claudia, Código Penal alemán: del 15 de mayo de 1871, con la última reforma del 31 de enero de 1998, Bogotá: Universidad Externado de Colombia, 1999, § 33.

3 MARTÍNEZ GARAY, Lucía, La imputabilidad penal: concepto, fundamento, naturaleza jurídica y elementos, Valencia: Tirant lo Blanch, 2005, p. 357.
} 


\section{Polít. Crim. Vol. 14, № 28 (Diciembre 2019), Art. 2, pp. 54-94. [http://politcrim.com/wp-content/uploads/2019/10/Vol14N28A2.pdf]}

que, desde el punto de vista dogmático, el miedo insuperable responde a lo que Labatut designó: impulso irresistible. Es decir, argumentaremos que el miedo insuperable presenta un grado de perturbación mayor a la atenuante de arrebato u obcecación y menor a la inimputabilidad. Consideración vinculada a la admisibilidad de una corriente fenomenológica ${ }^{4}$ que nos permita explicar por qué es posible erradicar la exigencia de subsidiariedad y proporcionalidad en el miedo insuperable, y cómo reconducir esta eximente solo a perturbaciones en las que el agente puede distinguir entre acto perceptivo e imaginario. ${ }^{5}$ Última diferenciación que sería expresión de los trastornos mentales que subyacen al miedo insuperable. Sin embargo, ello implica sostener, también contra un sector importante de la doctrina, que en casos de peligro imaginario o agresión imaginaria no es el miedo insuperable lo que se debe aplicar, sino más bien el error de prohibición en torno a una teoría de la culpabilidad que remite a las consecuencias. ${ }^{6}$ Sin embargo, en caso

\footnotetext{
${ }^{4}$ En este sentido, cuando aludimos a la fenomenología hacemos referencia a los lineamientos de obra de Husserl, con el objeto de establecer una graduación de la intensidad de los trastornos en el Derecho penal y establecer un puente con la Psiquiatría. La fenomenología de Husserl entrega un tratamiento a la intención en contraposición al psicologismo de Brentano e incluso el empirismo que nos parece interesante explorar. De ahí que lo interno o externo, en consonancia a la posición de Husserl, sea más bien una unidad que se observa aparentemente en el modelo finalista de Hans Welzel. Pues bien, "la diferencia entre antijuridicidad y culpabilidad no radica en la contraposición de 'externo e interno', sino en la diferencia entre la acción como una unidad de 'externo e interno' y el 'poder en lugar de ello' del autor para su acción", WELZEL, Hans, Derecho penal alemán, Trad.: BUSTOS RAMÍREZ, Juan; YÁÑEZ PÉREZ, Sergio, $11^{\mathrm{a}}$ ed., Santiago: Editorial Jurídica de Chile, 1970, p. 64. También respecto a cómo la teoría fenomenología de Husserl entregó solidez a la teoría de la acción finalista, véase LARENZ, Karl, Metodología de la Ciencia del Derecho, RODRÍGUEZ MOLINERO, Marcelino, 2a ed., Barcelona: Editorial Ariel, 1980, pp. 133 y ss. Por último, es importante indicar que Welzel prefiere utilizar la palabra finalidad y no intención en la línea de la fenomenología de Husserl, en atención al riesgo de inducir a confusión a los lectores de su obra, véase WELZEL, Hans, El nuevo sistema de Derecho penal. Una introducción a la doctrina de la acción finalista, Trad.: CEREZO MIR, José, Buenos Aires: Editorial B de F, 2004, p. 29.

${ }^{5}$ Se puede observar como el finalismo de Welzel pudo enlazar con la corriente fenomenológica de Husserl en GARCÍA PABLOS DE MOLINA, Antonio, Introducción al Derecho Penal: Instituciones, fundamentos y tendencias del Derecho Penal, Madrid: Editorial Universitaria Ramón Areces, 2012, p. 672. Asimismo, la fenomenología de Husserl tiene incidencia en los planteamientos psiquiátrico-chilenos en OJEDA, César, $L a$ tercera etapa: Ensayos críticos sobre psiquiatría contemporánea, Santiago (Chile), Cuatro Vientos, 2003, p. 80. También se reconoce con matices los aportes de Husserl a la psicopatología en CAPPONI M., Ricardo, Psicopatología y semiología psiquiátrica, 12a ed., Santiago (Chile): Universitaria, 2011, pp. 30 - 31.

${ }^{6}$ En este sentido, debemos indicar que desde la teoría del dolo "un error de tipo cuanta como un error que excluye la representación de la circunstancias fácticas de las cuales depende la realización del tipo delictivo a través del comportamiento de cuya imputación se trata, esto es, como un error de hecho; y un error de prohibición cuenta como un error que excluye la representación del carácter ilícito (o contrario a derecho) de aquel comportamiento que en las circunstancias fácticas dadas conlleva la realización del tipo, esto es, un error de derecho". De ahí que una "suposición errónea de circunstancias fácticas bajo las cuales el comportamiento objetivamente satisfaría el supuesto de hecho de una causal de justificación (por ejemplo, a modo de legítima defensa)... contará como un error de tipo permisivo, cuyas consecuencias tendrían que ser idénticas a un error de tipo; en cambio, si el error consiste en la suposición errónea del carácter supuestamente permitido del comportamiento... el error contará como un error de prohibición indirecto", MAÑALICH, Juan Pablo, "Informe en Derecho: Error de tipo y error de prohibición en los delitos contra la autodeterminación sexual", Departamento de Estudios de la Defensoría Penal Pública, no 2, (2011), pp. 48, pp. 1-2. Sin embargo, una teoría de la culpabilidad que remite a las consecuencias jurídicas "podría considerar que un error en las circunstancias fácticas de las cuales depende la satisfacción del supuesto de hecho de una causal de justificación sería un error de prohibición, pero que ha de ser sostenido al régimen de punibilidad y penalidad propio del correspondiente delito imprudente", MAÑALICH, "Informe en Derecho", cit. nota n ${ }^{\circ} 6$, p. 9, nota 14. Asimismo, nuestro modelo de culpabilidad se desarrolla en consonancia con el modelo de
} 
de adherir a la teoría del dolo, la repercusión de un peligro imaginario en el miedo insuperable solo tendría lugar en el error de tipo, porque el trastorno no condicionaría el acto de percepción y el error recaería sobre los presupuestos fácticos de una norma de permisión. ${ }^{7}$

La aceptación de la noción de impulso irresistible exige en el miedo insuperable una graduación del trastorno mental, de acuerdo a lo que se expondrá más adelante. De ahí que esta graduación no es simplemente razonable, sino dogmáticamente necesaria. Esa es la razón por la que en un sector de la dogmática se ha hecho cargo de esta problemática y reconoce la viabilidad de la propuesta enunciada. ${ }^{8}$ Es decir, el reconocimiento de trastornos mentales que no son parte de la psicosis en el miedo insuperable. Pese a ello, dada la indeterminación de la intensidad del trastorno mental que subyace al miedo insuperable $-\mathrm{y}$ dada la ausencia e imposibilidad de una regulación explícita que establezca una graduación fija de estos - una reconstrucción fundada exige reconocer que el miedo insuperable se encuentra configurado de una forma tal que solo exige males reales. Esto es, el reconocimiento de una norma de exculpación que es flexible en torno a los requisitos de proporcionalidad y subsidiariedad - tanto en casos de legítima defensa como estado de necesidad - en atención a supuestos que contempla se reducen a la presencia de un mal o peligro real y a la exigencia la intensidad del trastorno mental.

Con ello, pese a la apariencia de ampliación del miedo insuperable, en realidad los de un cierto grado de trastorno mental. El objeto central de este artículo es demostrar cómo en el miedo insuperable la intensidad del trastorno mental conlleva el reconocimiento de aquellos trastornos que no alteran el juicio de la realidad. Por último, trataré las consecuencias que siguen a esta interpretación en el estado de necesidad, la convergencia en el reconocimiento dogmático y jurisprudencial en el miedo insuperable de cierto tipo de trastornos mentales, el solo reconocimiento de males reales en esta última eximente $\mathrm{y}$, finalmente, una propuesta de diferenciación entre acto perceptivo e imaginario ante la existencia de peligros internos o externos a los que dé lugar el miedo insuperable.

imputación de Hruschka. Sobre las críticas que se plantean a este modelo (Hruschka) desde el concepto de dolus malus, véase WILENMANN, Javier, "Injusto, justificación e imputación. La teoría de la antijuricidad en la dogmática penal”, en: MAÑALICH, Juan Pablo (Coord.), La antijuridicidad en el Derecho penal, Buenos Aires: B de F, pp. 99 - 176, p. 171 nota 118. En esta línea, se critica el incorporar el análisis de la conciencia de antijuricidad en la imputación de segundo nivel o imputación fáctica.

${ }^{7} \mathrm{Si}$ bien existe discusión en la doctrina chilena en torno a qué es el error de prohibición, nosotros entendemos por este la "discordancia entre la representación (ex ante) del carácter antijurídico o prohibido de una conducta y la existencia de esa antijuricidad (ex post). Si la discordancia se da entre la representación (ex ante) del carácter permitido de una conducta y la efectiva permisión (ex post) por el ordenamiento, hablamos de error de permisión (en materia de causas de justificación)", SÁNCHEZ-OSTIZ, Pablo e IÑIGO CORROZA, Elena, Delictum 2.0, $2^{\text {a }}$ ed., Navarra (España): Thomson Reuters, 2014, p. 266. Por su parte, respecto de la discusión en torno al error de prohibición en el sistema jurídico-penal chileno, véase HERNÁNDEZ BASUALTO, Héctor, “Comentario al art. 10 No 1 del Código Penal”, en: COUSO SALAS, Jaime; HERNÁNDEZ BASUALTO, Héctor (Dirs.), Código Penal Comentado. Parte General. Doctrina y jurisprudencia, Santiago: AbeledoPerrot-LegalPublishing, 2011, pp. 80-90, pp. 89 y ss.

${ }^{8}$ En el modelo jurídico alemán se reconoce dogmáticamente la graduación de la intensidad de los trastornos mentales, como una propuesta de articulación entre las consideraciones del perito y el juez, en FRISTER, Helmut, Die Struktur des "voluntativen Schuldelements": Zugleich eine Analyse des Verhältnisses von Schuld und positiver Generalprävention, Berlin: Duncker \& Humbolt, 1993, pp. 129, 137, 139, 145, 146 nota 176. 
En síntesis, mi pretensión es estudiar y analizar el Derecho penal chileno vigente, con el objeto de introducir una distinción dogmática en la que el Derecho penal y la Psiquiatría forense puedan dialogar, lo que implica que todos los conceptos jurídicos penales enunciados están formulados en términos normativos. Es decir, que este fenómeno es tematizado por el Derecho penal, porque guarda sintonía con él o "resuena en concordancia, al ser estimulado [...] por el sonido [de] su estructura". 9

\section{Antecedentes históricos y sistemática del miedo insuperable}

\subsection{Extensión del estado de necesidad a través del miedo insuperable}

El Código penal chileno de 1874 presenta una regulación del estado de necesidad que se mantiene en la actualidad en el art. $10 \mathrm{~N}^{\circ}$ 7. Esta regulación durante la década de los sesenta y setenta será insuficiente — en la dogmática chilena - para resolver los problemas que se presenten en casos de necesidad, donde se afecten bienes jurídicos diferentes de la propiedad. El miedo insuperable, debido a la consideración dogmática de un mal inminente y grave, será muchas veces la respuesta para aquellos casos de estado de necesidad imposibles de considerar en el art. $10 \mathrm{~N}^{\circ} 7 .{ }^{10}$ En este contexto, Gandarillas —en las actas de la Comisión - se pronunció contra el uso de la palabra miedo en la disposición del art. $10 \mathrm{~N}^{\circ}$ 9, debido a la ambigüedad e indeterminación que podría originar el término. Sin embargo, su opinión no afecta la formulación final de la disposición. La Comisión Redactora de nuestro CP fusionó la fuerza irresistible y el miedo insuperable eliminando en el caso del miedo el requisito de un mal mayor. En las actas de la Comisión no hay constancia de por qué se dejó fuera el requisito de mal mayor presente en la disposición del miedo insuperable del CP español. No obstante, esto no implica que no se hubiera analizado la cuestión, porque en la $6^{\mathrm{a}}$ sesión de la Comisión, última parte, se puede identificar que existió una discusión extendida respecto de las disposiciones del CP español. $^{11}$

Posiblemente, las razones de por qué se dejó fuera este requisito del miedo insuperable se encuentran en los comentarios de Pacheco, que seguramente los miembros de la Comisión tuvieron a la vista. ${ }^{12}$ Se critica la idea de exigir a aquella persona perturbada por un miedo insuperable evitar un mal mayor que el provocado, "motivo que, sin lugar a dudas, los

\footnotetext{
${ }^{9}$ RODRÍGUEZ, Darío;TORRES, Javier, “Autopiesis, la unidad de una diferencia: Luhmann y Maturana”, Sociologías, Porto Alegre, año 5, $\mathrm{n}^{\circ}$, (2003), pp. $106-140$, p. 130, en: http://www.scielo.br/pdf/soc/n9/n9a05.pdf [visitado el 22.08.2017].

${ }^{10}$ En este contexto, debemos recordar que Rivacoba indicó que era inadecuado pretender entregar una respuesta al problema del estado de necesidad exculpante por medio de otras eximentes en el Código penal chileno. No obstante, reconoce los esfuerzos por tratar de responder el problema, señalado que "el legalismo característico de la doctrina chilena ha discurrido arbitrios llenos de ingenio, pero inaceptables", RIVACOBA Y RIVACOBA, Manuel, "Estudio preliminar", en: Código Penal de la República de Chile. Actas de las sesiones de la comisión redactora, Valparaíso: Edeval, 1974, p. 104.

${ }^{11}$ COMISIÓN REDACTORA DEL CÓDIGO PENAL CHILENO, Código Penal de la República de Chile y Actas de las sesiones de la Comisión Redactora, con un estudio preliminar de Manuel de Rivacoba y Rivacoba, Valparaíso: Edeval, 1974, p. 254.

${ }^{12}$ PACHECO, Joaquín Francisco, El Código Penal concordado y comentado, Madrid: Imprenta de la Viuda de Perinat y Compañía, 1888, p. 172.
} 
indujo a la supresión de esta absurda limitación". ${ }^{13}$ Así pues, la eliminación de la frase de un mal mayor responde a identificar el miedo insuperable con una caracterización psicológica que es ajena a las causales de justificación. ${ }^{14} \mathrm{Si}$ bien se reconocerá un origen psicológico-subjetivo en la eximente del miedo insuperable, será vinculado con la exigencia objetiva de un mal actual, inminente y grave que pueda padecer el agente. Lo último, debido al requisito de insuperabilidad de la eximente en cuestión. ${ }^{15}$ Sin embargo, tal reconocimiento objetivo del mal será parcial, porque parte de la doctrina nacional aceptará la presencia de males irreales que provengan de la perturbación de ánimo del agente donde lo relevante sería la presencia de esta última. ${ }^{16}$ Punto también controvertido en la doctrina española, cuya posición mayoritaria exige un mal real para dar lugar a la eximente, considerando frente a la irrealidad del mal recurrir a las reglas del error de prohibición. ${ }^{17}$

\subsection{Origen del miedo insuperable y su vinculación con el estado de necesidad}

Uno de los primeros trabajos en los que se comienza a relacionar el miedo insuperable con el estado de necesidad es en el de Fuensalida en 1883. En este el autor indicó, en su comentario al CP, que el miedo insuperable del art. $10 \mathrm{~N}^{\circ} 9$ posee por "fundamento una causa análoga"18 a la del art. $10 \mathrm{~N}^{\circ} 7$. Fuensalida sustentó que si al causar un daño a la propiedad, en un caso de estado de necesidad, se demanda causar un mal inferior al que se pretende evitar, con mayor razón se debe imponer la exigencia en una disposición que, como el miedo insuperable, permite dañar a las personas. ${ }^{19}$ El razonamiento de Fuensalida

${ }^{13}$ COUSIÑO MAC IVER, Luis, Derecho penal chileno. Parte general. t. I, Santiago:Editorial Jurídica de Chile, 1979, p. 507.

${ }^{14}$ Así, reconoce un origen psicológico subjetivo en la eximente ETCHEBERRY ORTHUSTEGUY, Alfredo, Derecho Penal, t. I, $3^{\text {a }}$ ed., Santiago: Jurídica de Chile, 1998, p. 347. Sin embargo, este considera que la eximente, carente de todo elemento objetivo presente en las causales de justificación, requiere que el sujeto tema un mal actual o inminente y grave. Lo último, debido al requisito de insuperabilidad de la eximente. No obstante, el autor reconoce en otro de sus trabajos, en alusión a una Sentencia de la Corte de Apelaciones de Iquique del 16 de diciembre de 1939 que el miedo insuperable es "la especie de perturbación mental causada por la aprehensión de algún peligro o mal aparente o real que se teme o recela", ETCHEBERRY ORTHUSTEGUY, Alfredo, El Derecho penal en la jurisprudencia, t. II., Concepción: S. Muñoz Vera, 1971, p.124.

${ }^{15}$ ETCHEBERRY, Derecho Penal, cit. nota ${ }^{\circ} 14$, p. 347.

${ }^{16}$ Realidad e irrealidad del mal en el miedo insuperable que será aceptada en la doctrina nacional en NÁQUIRA, Jaime, Derecho Penal. Teoría del Delito I, Santiago: Editorial McGrawHill, 1998, p. 424; MAÑALICH, Juan Pablo, "El estado de necesidad exculpante. Una propuesta de interpretación del artículo 10 N 11 del Código Penal Chileno", en: VAN WEEZEL, Alex (Ed.), Humanizar y renovar el Derecho penal. Estudios en memoria de Enrique Cury, Santiago: LegalPublishing, 2013, p. 742; CURY, Enrique, Derecho Penal. Parte General, $7^{\mathrm{a}}$ ed., Santiago: Ediciones Universidad Católica de Chile, 2005, p. 458; GARRIDO MONTT, Mario, Derecho Penal. Parte general, t. II, 4 ed., Santiago: Editorial Jurídica de Chile, 2007, p. 317. Sin embargo, otros autores serán de la idea de que esta eximente solo comprende males reales, graves e inminentes, véase POLITOFF LIFSCHITZ, Sergio, et al., Lecciones de Derecho Penal. Parte General, $t$. I, $2^{\mathrm{a}}$ ed., Santiago: Editorial Jurídica de Chile, 2003, p. 347; BULLEMORE, Vivian; MACKINNON, John, Curso de Derecho Penal, Teoría del delito, $t$. II, $2^{\text {a }}$ ed., Santiago: LexisNexis, 2007, p. 145.

${ }^{17}$ Véase QUINTERO OLIVARES, Gonzalo, Parte General del Derecho Penal, $4^{\mathrm{a}}$ ed., Barcelona: Thomson Reuters-Aranzadi, 2010, pp. 597-598; HIGUERA GUIMERÁ, Juan Felipe, La eximente del miedo insuperable en el derecho penal común y militar español, Barcelona: Bosch, 1991, p. 123.

${ }^{18}$ FUENSALIDA, Alejandro, Código Penal Chileno, t. I, Lima: Imp. Comercial Calle del Huallacan $n^{\circ} 139$, 1883 , p. 61.

${ }^{19}$ FUENSALIDA, Código Penal Chileno, cit. nota $\mathrm{n}^{\circ} 18, \mathrm{p} .61$. Nos cuesta creer que el primer comentador "autodidacta" haya solamente aplicado de forma literal los comentarios de Pacheco. Si bien su pensamiento 


\section{Polít. Crim. Vol. 14, № 28 (Diciembre 2019), Art. 2, pp. 54-94. [http://politcrim.com/wp-content/uploads/2019/10/Vol14N28A2.pdf]}

se distancia en este aspecto de los comentarios de Pacheco alusivos a suprimir la frase de un mal mayor en el miedo insuperable. Así pues, Fuensalida no concibe cómo poder comprender el miedo insuperable sin una frase de dichas características. La razón de ello radica en que el autor observa en el miedo insuperable la posibilidad de comparar "el mal que es necesario ocasionar para evitar aquel". ${ }^{20}$ Por ende, para Fuensalida, "comparando los males $[\ldots]$ la frase [de un mal mayor] resulta propia i sirve para precisar la vaguedad de las palabras «miedo insuperable»". ${ }^{21}$

Sin embargo, Pacheco piensa que en el miedo recae una violencia moral que presiona al agente en su voluntad, haciendo alusión solo a una perturbación de ánimo para explicar el comportamiento del agente. Nos parece que Pacheco presenta una lectura del miedo que concibe su insuperabilidad solo desde una perspectiva subjetiva, porque, desde su perspectiva, el agente logra tranquilizar su fuero interno al momento de realizar la acción. En esta línea, Pacheco parece que presenta casos de estado de necesidad exculpante explicándolos desde la perspectiva del miedo insuperable. ${ }^{22}$ Si bien el modo en que Pacheco hace uso del miedo insuperable no tiene relación con la noción actualmente asentada en la dogmática chilena, no debe concedérsele injusta intrascendencia. ${ }^{23}$ En efecto, nos parece interesante que Pacheco mencione como casos de miedo insuperable una serie de situaciones en las que posiblemente se puede apreciar tanto un comportamiento deliberadamente racional, propio del estado de necesidad, como una perturbación de ánimo que no necesariamente lleva a la psicosis o inimputabilidad. ${ }^{24}$ Lo último, debido a que no es posible centrar siempre la explicación de todos los casos en una perturbación de ánimo. ${ }^{25}$

El primero de los casos que enuncia Pacheco consiste en que un grupo de revolucionarios toman a una persona y la obligan a participar en su sublevación bajo amenaza de muerte, encontrándose eximido de responsabilidad dicho comportamiento. El segundo caso apunta a un grupo de bandidos que toman a una persona, obligándola a quemar una casa o enterrar un cuchillo en el pecho a un prisionero bajo amenaza de muerte. En este segundo caso el autor menciona que existen males equivalentes; por consiguiente, nadie podría reprender

no se distancia mucho de este último autor, Fuensalida presenta una lectura propia del miedo insuperable que posiblemente podría estar ligada a lo que hoy entenderíamos por un estado de necesidad exculpante. Sin embargo, en la doctrina nacional solo se resalta que tanto Fuensalida como Fernández copiaron de forma literal a Pacheco, MATUS, "La doctrina penal", cit. nota $n^{\circ} 1$, p. 158; MATUS ACUÑA, Jean Pierre, "Fernández, Fuenzalida y Vera: Comentaristas, autodidactas y olvidados. Análisis diacrónico y sincrónico de la doctrina penal chilena del siglo XIX”, Revista Ius et Praxis, vol. 12, $\mathrm{N}^{\circ} 1$ (2006), pp. 31 - 67, passim. Esto sin dar cuenta de algunos de los matices que realizan los autores que difieren de lo expresado por Pacheco en sus comentarios. Lo último, sobre todo en lo que respecta al problema de interferencia en el estado de necesidad.

${ }^{20}$ FUENSALIDA, Código Penal Chileno, cit. nota ${ }^{\circ}$ 18, p. 62.

${ }^{21}$ FUENSALIDA, Código Penal Chileno, cit. nota n ${ }^{\circ}$ 18, p. 62.

${ }^{22}$ PACHECO, El Código Penal concordado, cit. nota n ${ }^{\circ}$ 12, pp. 172-173.

${ }^{23}$ La dogmática nacional converge en que el miedo insuperable constituye "un estado de perturbación anímica más o menos profunda, provocada por la previsión del acaecimiento actual o inminente de un mal grave", HERNÁNDEZ BASUALTO, Héctor, "Comentario al art. 10 No 9 del Código Penal", en: COUSO SALAS, Jaime; HERNÁNDEZ BASUALTO, Héctor (Dirs.), Código Penal Comentado. Parte General. Doctrina y jurisprudencia, Santiago: AbeledoPerrot-LegalPublishing, 2011, pp. 250- 260, p. 253.

${ }^{24}$ Perturbación que desde los estudios de Capponi es constitutiva de un trastorno del sentido de la realidad, CAPPONI M., Ricardo, Psicopatología, cit. nota n ${ }^{\circ}$ 5, p. 239.

${ }^{25}$ PACHECO, El Código Penal concordado, cit. nota n ${ }^{\circ}$ 12, pp. 172-173. 
dicho comportamiento porque la persona busca salvar su propia vida. El tercer caso hace nuevamente referencia a una hipótesis en la cual una persona es capturada por un grupo de bandidos que la obligan a quemar una casa; esta vez la amenazan con mutilarla; cortándole una mano. En dicho caso el mal que se pretende evitar no es tan grave como quemar una casa. Sin embargo, el autor interpela al lector indicando que pese a que el mal que se pretende evitar es menor (corte de la mano), se pregunta quién será el juez que se atreva a condenar a esta persona, pese al tenor literal de la disposición que apunta a evitar un mal menor en el modelo español. ${ }^{26}$

Considerando este razonamiento de Pacheco, Fernández (el segundo de nuestros comentaristas del CP chileno) estimó que el miedo es más difícil de interpretar que la fuerza irresistible. Conectando con el planteamiento que tuvo en un comienzo Gandarillas, como miembro de la Comisión Redactora del Código, al indicar que el término miedo era sumamente dudoso en cuanto a su extensión, Fernández volverá a caracterizar el miedo como una expresión vaga e imprecisa. Fernández constató, al igual que Fuensalida, que la Comisión en las actas no expresó los motivos de por qué eliminó la expresión un mal mayor en la eximente del miedo insuperable. Sin embargo, aseguró que la razón de ello radicó en que tenían a su disposición los comentarios de Pacheco. Así, Fernández hará alusión a lo innecesario de la expresión de un mal mayor, considerando los ejemplos que presentó Pacheco en sus comentarios. ${ }^{27}$

\subsection{Límites del impulso irresistible en el miedo insuperable}

\subsubsection{Primeras distinciones en la dogmática chilena entre coacción moral y miedo insuperable}

Cabieses en 1915 parece ser el primer tratadista en la dogmática chilena que identificó al miedo insuperable con un elemento psicológico, pues relacionó la eximente con una fuerza moral que incide en el espíritu del agente presionándolo a cometer un delito. De tal modo, afirmó que el caso de aquel muchacho que presta falso testimonio por las amenazas de su patrón entra en el miedo insuperable porque limita su libertad. Limitación que se refleja en la decisión que tomó el agente presionado por el peligro de la amenaza. Presión que incidirá de forma diferente en el agente, tratándose de un niño, hombre o mujer. Asimismo, sostuvo que el daño que se pretenda enfrentar puede recaer sobre la propiedad, parientes del agente o su cónyuge. ${ }^{28}$ No obstante, dicho reconocimiento del origen psicológico de la eximente nos parece que relaciona el miedo insuperable con una acción que no se condice necesariamente con una perturbación de ánimo de la entidad que requiere la eximente.

\footnotetext{
${ }^{26}$ Sin embargo, con posterioridad, se reconocerá en 1998 que el temor a sufrir una mutilación es suficiente para exculpar a una persona de cometer homicidio. Opinión que será sostenida por Náquira, al reconocer que, al igual que un grupo importante de autores de la doctrina nacional, el miedo puede ser real o imaginario. Considerando que es suficiente para que proceda la aplicación de esta eximente la presencia de un mal grave, teniendo en cuenta la falta de exigencia en nuestro modelo legislativo de un mal mayor en el caso de la eximente en cuestión, NÁQUIRA, Jaime, Derecho Penal, cit. nota n ${ }^{\circ} 16$, pp. 424-425.

27 FERNÁNDEZ, Pedro Javier, Código Penal de la República de Chile. Esplicado $i$ Concordado, $2^{\mathrm{a}}$ ed., Santiago: Imprenta, litografía i Encuadernación Barcelona, 1899, p. 96.

${ }^{28}$ CABIESES, Ricardo, Derecho penal: Apuntes tomados en clase correjidos $i$ aumentados por R. B. P. $i$ P. G. G., Santiago: Editorial Universitaria, 1915, p. 132. El autor fundamentó su opinión siguiendo el razonamiento de la Sentencia de la CS del 13 de mayo de 1882, GJ, 1882, s. 856, p. 475.
} 
Si alguien amenaza a otro, no necesariamente genera una perturbación de ánimo que afecte su decisión. Posiblemente, el agente pueda sentirse asustado, nervioso o temeroso ante la situación de peligro; sin embargo, la decisión de llevar a cabo la acción podría responder a una decisión racional que deberá apreciarse bajo los parámetros objetivos del estado de necesidad. ${ }^{29}$ También el Proyecto de Reforma de 1946 identificó al miedo con una coacción moral. La disposición que aludía al miedo insuperable en el Proyecto erradicó la palabra miedo sustituyéndola por la de mal. Así, la disposición del art. $11 \mathrm{~N}^{\circ} 4$ fue redactada del siguiente modo: "el que obra compelido por la amenaza de un mal insuperable, inminente y grave, que no está obligado a soportar". La vinculación del miedo con la coacción moral se puede observar en la jurisprudencia. De dicha orientación es la sentencia dictada por la Corte de Apelaciones de San Miguel, contra Rafael Espinoza Elgueta, del 23 de abril de 1993, que determinó:

"que si bien el procesado confesó su participación en el hecho investigado [este] tenía una imperiosa necesidad de trabajar como chofer, al tener que mantener a una familia que, además, componen su cónyugue [sic] y cinco hijos de edad escolar" ${ }^{\prime 30}$. La Corte indicó que "en el caso de autos no se encuentran en conflicto o colisión bienes jurídicos de idéntica naturaleza e igual valor, como tampoco afectado el derecho de propiedad, sino que, por el contrario, se enfrentan las necesidades básicas de un hombre y su familia con la fe pública, estimando los sentenciadores que aquel bien jurídico es de mayor importancia y valor que éste último". Así, la Corte determinó que el acusado: "al verse enfrentado [...] ante una situación de peligro actual e inminente, como era el hecho de no poder cubrir las necesidades de alimentación, habitación y vestuario [...] no presentándose otra posibilidad de poder evitarlo que no fuese por medio de seguir desempeñando su trabajo de chofer de una citroneta ajena [, se reúnen,] en concepto del tribunal, los requisitos necesarios para dar por establecida la existencia de un estado de necesidad" en el art. $10 \mathrm{~N}^{\circ} 9$.

Última comprensión jurisprudencial de la Corte de Apelaciones de San Miguel, entre otras sentencias, del estado de necesidad que, probablemente, llevó a García a observar una plataforma o base psicológica en el estado de necesidad exculpante. ${ }^{31}$ No obstante, lo

\footnotetext{
${ }^{29}$ De lo contrario, nos parece que lo adecuado sería acreditar la presencia de una afectación grave en la voluntad del agente que explique su trastorno del sentido de la realidad. Trastorno que no puede estar relacionado a una afectación del juicio de la realidad porque entraríamos en el plano de la inimputabilidad, CAPPONI, Psicopatología, cit. nota ${ }^{\circ}$ 5, pp. 238-239; JASPERS, Karl, Psicopatología general, Trad.: SAUBIDET, Roberto O.; SANTILLÁN, Diego A., 2 a ed., México, D.F.: Fondo de Cultura Económica, 1993, pp. 108-113.

${ }^{30}$ Sentencia de la Corte de Apelaciones de San Miguel, 23 de abril de 1993, RDJ, t. XC, 1993, segunda parte, secc. cuarta, pp. 52 y ss. Véase GARCÍA SOTO, María Paulina, El estado de necesidad en materia penal, Santiago: Jurídica ConoSur, 1999, pp. 444-450.

${ }^{31}$ GARCÍA, El estado de necesidad, cit. nota n ${ }^{\circ}$ 30, pp. 245 y 450. Perspectiva psicológica del estado de necesidad exculpante que es cuestionada en WILENMANN, Javier, "El fundamento del estado de necesidad justificante en el derecho penal chileno. Al mismo tiempo, introducción al problema de la dogmática del estado de necesidad en Chile", Revista de Derecho (Valdivia), vol. XXVII, no 1 (2014), pp. 213 - 244, p. 224, nota 23; ETCHEBERRY, El Derecho penal en la jurisprudencia, cit. $\mathrm{n}^{\circ} 14$, p. 124 . Respecto de este punto es importante considerar la Sentencia de la Corte Suprema del 13 de mayo de 1882, GT, 1882, s. 856, p. 475; Sentencia de la Corte de Apelaciones de Valparaíso del 28 de septiembre de 1914, GT, 1914, segundo semestre, s. 486, p. 1334; Sentencia de la Corte de Apelaciones de Santiago del 14 de septiembre de 1950,
} 
interesante de la disposición del art. $11 \mathrm{~N}^{\circ} 4$ y la sentencia de la Corte de Apelaciones recientemente enunciada es que ejemplifican lo difícil que continuaba siendo interpretar el miedo desde la época de Gandarillas. Por ello, nos parece que esta propuesta de reforma es una muestra de cómo la coacción moral intentó ser diferenciada del miedo insuperable. Sin embargo, la diferenciación apuntaba, por medio del obrar compelido, a crear una figura amplia de estado de necesidad exculpante. Figura libre del requerimiento de causar un mal inferior o equivalente al que se procura evitar. De tal modo, nos parece que es difícil establecer que, en la línea de Jiménez de Asúa, la disposición buscó redimir el carácter subjetivo de un trastorno mental propio del miedo insuperable. ${ }^{32}$

Así las cosas, la disposición del art. $11 \mathrm{~N}^{\circ} 4$ tuvo por objeto crear un estado de necesidad por coacción que no exigiera los requisitos del art. $10 \mathrm{~N}^{\circ} 7 .^{33}$ Razonamiento que desprendemos de este obrar compelido en el que deja de tener relevancia la referencia al miedo. Lo anterior, considerando la legislación vigente al momento de la elaboración del Proyecto. No obstante, existen registros en la doctrina chilena donde, con anterioridad al Proyecto de 1946, se aplicó la lógica inversa. Labatut, por ejemplo, buscó incorporar la coacción en el miedo y no el miedo en la coacción, remitiendo al miedo insuperable con el objeto de desprender de este un estado de necesidad más amplio. Al tratar el miedo insuperable, Labatut no hará referencia al mencionado art. $11 \mathrm{~N}^{\circ} 4$. Este relacionó el miedo insuperable no solo con la coacción, sino también con perturbaciones psíquicas que, eventualmente, podrían privar de razón al agente. Su interpretación fue tan amplia que buscó orientar el miedo insuperable, incluso, hacia el principio de inexigibilidad de otra conducta. $^{34}$

Nos parece que tanto la propuesta del Proyecto de 1946 como la de Labatut son inadecuadas. La primera porque prácticamente anula el miedo insuperable dentro de una formulación amplia de coacción moral. La segunda porque relativiza en exceso el campo del miedo insuperable llevándonos a perder su identidad, al subsumir en él figuras de estado de necesidad, trastornos mentales transitorios e incluso derivaciones del principio de no exigibilidad de otra conducta. Asimismo, no serán aislados los desacertados intentos de diferenciación entre el estado de necesidad y el miedo insuperable. De tal modo, la Corte Suprema en su sentencia, contra José Santiago Loyola Loyola, del 31 de diciembre de 1956, vincula, curiosamente, en un intento diferenciador, la inimputabilidad a la fuerza irresistible y el miedo insuperable. La Corte indicó:

"Que [en] las causas de inimputabilidad, el acto antijurídico o ilícito, no desaparece, pero, la ley atiende al sujeto en cuanto no concurre en él la salud o desarrollo mentales [sic] o la plenitud de conciencia o espontaneidad. Así ocurre, por ejemplo,

$R C P$, t. XII, julio-septiembre de 1950, pp. 73 y ss.; Sentencia de la Corte de Apelaciones de San Miguel, 30 de septiembre de 1969, RDJ, t. LXVI, 1969, segunda parte, secc. cuarta, considerando 6, p. 263.

32 JIMÉNEZ DE ASÚA, Luis, Tratado de Derecho penal, t. I, 4 ed., Buenos Aires: Editorial Losada, 1964, p. 1178 .

${ }^{33}$ CUERDA ARNAU, María Luisa, El miedo insuperable. Su delimitación frente al estado de necesidad, Valencia: Tirant lo Blanch, 1997, p. 43.

${ }^{34}$ LABATUT GLENA, Gustavo, Derecho Penal. Parte General, $9^{\text {a }}$ ed., Santiago: Jurídica de Chile, 2005, p. 149. 
cuando se obra impulsado por una fuerza irresistible o por un miedo insuperable $[\ldots]^{\prime \prime} .35$

Por otra parte, en la sentencia de la Corte de Apelaciones de Santiago, contra César Larredondo Álvarez, del 14 de septiembre de 1950, se da una equivalencia entre la coacción moral y el miedo insuperable. La Corte consideró que obrar "impulsado por miedo insuperable o coacción moral, [...] no [hace] desaparecer totalmente la voluntad del hechor, puesto que puede optar entre sufrir el mal con que se le amenaza o cometer el delito, su libertad de elección está viciada y en tal caso se le exime de responsabilidad penal, cuando el mal con que se le amenaza es inminente, grave, inevitable e injusto, produciéndose en el agente un estado peor que hace desaparecer su libre albedrío". "La equivalencia entre la coacción moral y el miedo insuperable, expresada en el razonamiento de la Corte, cae en la misma indiferenciación del Proyecto de 1946, que no logra rescatar la esencia del miedo insuperable porque esta eximente, a diferencia de la coacción (doctrina italiana) o estado de necesidad (doctrina alemana), sería capaz de incorporar una variante psicológica de perturbación a considerar ante la misma situación de peligro. En consecuencia, podemos constatar desde una perspectiva puramente objetiva del miedo, presente en Fuensalida, pasamos a una excesivamente subjetiva, en la década de los cincuenta, con la postura de Labatut.

Con todo, ninguna de estas posiciones explica cuándo la libertad o la motivabilidad son excluidas en razón de trastornos mentales. Pues bien, no recurren a parámetros valorativos para explicar cómo estas inciden en la ejecución del hecho. Si bien se observa en dichas posiciones interpretativas la búsqueda de un criterio empírico-psiquiátrico, no definen uno normativo que oriente la valoración jurídico-penal. También de estos planteamientos se desprende que, al igual que en las discusiones de la doctrina contemporánea, "la motivabilidad no parece ofrecer ventajas significativas respecto de la libertad como fundamento de la culpabilidad". 37 Por ello, denotan la falta de un criterio que defina qué es aquello propio de los trastornos mentales que nos permite atenuar o excluir la responsabilidad penal en sede de culpabilidad. Y como tal, requiere explicitar nuestra comprensión de la culpabilidad. Así las cosas, nos parece que la culpabilidad expresa un "juicio de imputación en sentido estricto que atiende a si el agente puede comprender las normas y obrar conforme a esa comprensión". "No seguir tal distinción supondría negar la condición negativa de motivarse conforme a lo establecido en ausencia de los presupuestos de la capacidad de culpabilidad o en casos exculpación en situaciones de inexigibilidad. ${ }^{39}$ De aquí que en la imputación jurídica se interrumpa "cuando al agente no le es posible...obrar conforme a la norma... tanto en casos de vis compulsiva (situaciones de

\footnotetext{
${ }^{35}$ Corte Suprema, 31 de diciembre de 1956, RDJ, Título LIII, $2^{\text {a }}$ parte, sección $4^{\text {a }}$, considerando sexto, p. 199.

${ }^{36}$ Sentencia de la Corte de Apelaciones de Santiago, 14 de septiembre de 1950, GT, 1950, s. 102, considerando quinto, p. 551. Sentencia citada en la misma línea en ALONSO ARIAS P., Antonio, El miedo insuperable y la fuerza o violencia moral e irresistible, Santiago: Ediar Conosur, 1985, p. 75; ETCHEBERRY, El Derecho penal en la jurisprudencia, cit. nota n ${ }^{\circ} 14$, p. 125.

${ }^{37}$ MARTÍNEZ, La imputabilidad penal, cit. nota $\mathrm{n}^{\circ}$ 3, p. 205

${ }^{38}$ SÁNCHEZ-OSTIZ, Pablo, La libertad en el Derecho penal. Estudios sobre la doctrina de la imputación, Barcelona: Atelier, 2014, p. 47.

${ }^{39}$ Respecto de la diferencia entre causas de inculpabilidad y exculpación, véase MAÑALICH, Juan Pablo, "Miedo insuperable y obediencia jerárquica", Revista de Derecho, vol. XXI, no 1 (2008), pp. 61 - 73, p. 65.
} 
estado de necesidad coactiva del $\S 35$ ), como de enfermedades o trastornos psíquicos en los que el sujeto no obra conforme a la norma (del $§ 20 \mathrm{StGB}) " .40$

\subsection{Exigencia de la presencia de un trastorno mental en el miedo insuperable}

La doctrina más tradicional estará conteste en que el miedo insuperable presenta una perturbación anímica que, frente a la ocurrencia de un mal grave, real o irreal, actual o inminente, no alcanza a privar de razón al agente. ${ }^{41}$ Manifiesta esta interpretación la sentencia de la Corte de Apelaciones, contra Ana Medina Soto, del 30 de septiembre de 1969, que estableció que el "miedo es una perturbación angustiosa del ánimo ocasionada por un peligro o mal, real o imaginario que amenaza; y es insuperable cuando se sobrepone de tal manera a la voluntad que la impulsa a la realización de hechos que sin él no hubieran sido ejecutados, dominando a la voluntad sin llegar a constituir una causal de inimputabilidad, sino una de no exigibilidad de otra conducta y que, genéricamente, se clasifica entre las de culpabilidad". ${ }^{2}$

Así, el miedo insuperable y el estado de necesidad se comenzarán a vincular en el sistema jurídico chileno al aceptar la posibilidad de comprender en el miedo insuperable males reales para la integridad corporal, la salud o la vida del agente. ${ }^{43}$ Razón por la cual se pretenderá diferenciar el miedo de un simple temor que sería compatible con un grado de reflexión que, presupuesto en el estado de necesidad, no perturbaría el ánimo del agente al modo que demanda el miedo insuperable. ${ }^{44}$ De ahí que se llegará a sostener que el terror y

${ }^{40}$ SÁNCHEZ-OSTIZ, Pablo, La libertad, cit. nota no 38, p. 46.

${ }^{41}$ NÁQUIRA, Jaime, Derecho Penal, cit. nota $\mathrm{n}^{\circ} 16$, p. 424; MAÑALICH, "El estado de necesidad exculpante", cit. nota ${ }^{\circ} 16$, p. 742; CURY, Derecho Penal, cit. nota ${ }^{\circ} 16$, p. 458; GARRIDO, Derecho Penal, cit. nota $\mathrm{n}^{\circ}$ 16, p. 317; POLITOFF, Lecciones de Derecho Penal, cit. nota $\mathrm{n}{ }^{\circ} 16$, p. 347; BULlEMORE, Vivian; MACKINNON, John, Curso de Derecho Penal, cit. nota $\mathrm{n}^{\circ} 16$, p. 145; ETCHEBERRY, Derecho Penal, cit. nota n ${ }^{\circ}$ 14, p. 348.

${ }^{42}$ Sentencia de la Corte de Apelaciones de Santiago, 30 de septiembre de 1969, RDJ, 1969, t. LXVI, secc. cuarta, p. 263.

${ }^{43}$ Sin embargo, no podemos desconocer una serie de fallos que reconocen casos de inimputabilidad en el miedo insuperable haciendo caso omiso de la doctrina. Cabe destacar la Sentencia de la Corte de Apelaciones de Chillán del 10 de mayo de 1954. En esta sentencia podemos identificar que la Corte determinó, considerando el informe médico de los psiquiatras que sostuvieron que la procesada padecía un trastorno mental profundo provocado por un terror patológico y epilepsia estriada, "forzoso concluir que al asesinar a su marido mientras dormía [la acusada] se encontraba en un período de locura transitoria, que la exime de responsabilidad criminal, por lo que concurren en su favor las circunstancias de inimputabilidad criminal de los números $1^{\circ}$ y $9^{\circ}$, del art. 10 del CP”, Sentencia de la Corte de Apelaciones de Chillán del 10 de mayo de $1954, R D J$, t. LII, 1955, secc. cuarta, p. 211. Jurisprudencia que considera el miedo insuperable dentro de una causal de inimputabilidad (trastorno mental transitorio o privación temporal de la razón) se observa en Sentencia de la Corte de Apelaciones de Valparaíso, 10 de octubre de 1919, GT, s. 193, p. 792; Sentencia de la Corte de Apelaciones de Concepción, 16 de julio de 1947, GT, 1947, s. 83, p. 437; Sentencia de la Corte Suprema, 11 de octubre de 1967, RDJ, t. LXII, 1965, secc. cuarta, p. 294.

${ }^{44} \mathrm{Sin}$ embargo, en la doctrina española existe interpretaciones del miedo insuperable que hacen admisible la ponderación de males en la línea del estado de necesidad. Estas interpretaciones exploran la aplicación del principio del mal menor en el miedo insuperable y no una graduación de trastornos que incida en el tratamiento de la eximente en casos de exceso de legítima defensa o estado de necesidad, véase VARONA GÓMEZ, Daniel, El miedo insuperable: una reconstrucción de la eximente desde una teoría de justicia. Estudios de Derecho penal dirigidos por Carlos María Romero Casabona, Granada: Editorial Comares, 1999, pp. 17-20. También esta interpretación se observa en torno a la excusa de duress en VARONA GÓMEZ, Daniel, "El miedo insuperable y la ética del hormigueo: reflexiones sobre el papel de las eximentes 


\section{Polít. Crim. Vol. 14, No 28 (Diciembre 2019), Art. 2, pp. 54-94. [http://politcrim.com/wp-content/uploads/2019/10/Vol14N28A2.pdf]}

el espanto serán emociones que pueden exceder el miedo, logrando nublar temporalmente el ánimo del agente. Pues bien, el término insuperable no alude a que el agente pierda contacto total con la realidad (art. $10 \mathrm{~N}^{\circ} 1$ ), sino más bien a una perturbación grave frente a la existencia de un mal que revista cierto peligro para la salud, integridad corporal o vida del agente. Lo último, pese a que nuestra legislación no restrinja expresamente la disposición a este tipo de situaciones. ${ }^{45}$

Asimismo, en la aplicación de la eximente existirán ciertas restricciones. No podrían solicitarla aquellos agentes que tengan una formación profesional que les permita afrontar determinados peligros inherentes a ella. ${ }^{46}$ Para eximir de responsabilidad, la perturbación ha de ser grave; es decir, capaz de intimidar a un hombre prudente. Tal perturbación debe dejarlo imposibilitado de enfrentar el mal de una forma adecuada a los parámetros del estado de necesidad o a la legítima defensa. Habitualmente, se toma como parámetro de apreciación el criterio hombre medio. ${ }^{47}$ Sin embargo, este nos parece difícil de aplicar en el miedo insuperable porque requiere de una arista individual que no solo considera la psiquis del autor, sino también la situación personal del agente en la situación concreta. ${ }^{48}$ Por ello,

fundadas en la inexigibilidad de otra conducta”, Revista de Estudios de la Justicia, nº 12 (2010), pp. 59-94, pp. 68 y ss.

${ }_{45}$ Véase LABATUT, Derecho Penal, cit. nota ${ }^{\circ}$ 34, p. 149; NOVOA MONREAL, Eduardo, Curso de Derecho Penal chileno. Parte General, t. I, $3^{\text {a }}$ ed., Santiago: Jurídica de Chile, 2005, p. 565; ETCHEBERRY, Derecho Penal, cit. nota ${ }^{\circ}$ 14, pp. 347-348; CURY, Derecho Penal, cit. nota n ${ }^{\circ} 16$, p. 458; POLITOFF, Lecciones de Derecho Penal, cit. nota ${ }^{\circ} 16$, p. 345, entre otros. En contra, NÁQUIRA, Jaime, Derecho Penal, cit. nota $\mathrm{n}^{\circ} 16, \mathrm{p} .432$.

${ }^{46}$ Así, soldados, bomberos y policías, que se dedican a ejercer actividades que no podrían ser toleradas sin causar algunas posibles perturbaciones, podrían invocar la eximente en circunstancias extraordinarias.

${ }^{47}$ CURY, Enrique, Derecho Penal, cit. nota ${ }^{\circ} 16$, p. 458; GARRIDO, Derecho Penal, cit. nota ${ }^{\circ} 16$, pp. 317-318.

${ }^{48}$ A favor de un criterio subjetivo, NÁQUIRA, Jaime, Derecho Penal, cit. nota ${ }^{\circ}$ 16, p. 426; LABATUT, Derecho Penal, cit. nota ${ }^{\circ}$ 34, p. 149; POLITOFF LIFSCHITZ, Sergio y ORTIZ QUIROGA, Luis, Texto y comentario del Código Penal Chileno, t. I, Santiago: Jurídica de Chile, 2002, pp. 148-149; PRAMBS JULIÁN, Claudio, El tipo de culpabilidad en el Código Penal Chileno. Una visión sistemática Normativa y Positiva, Santiago: Editorial Metropolitana, 2005, p. 233; VILLEGAS DÍAZ, Myrna, "Homicidio de la pareja en violencia intrafamiliar. Mujeres homicidas y exención de responsabilidad penal", Revista de Derecho, vol. XXIII, $\mathrm{n}^{\circ} 2$ (2010), pp. 149 - 174, p. 166. En este contexto, nos parece que existen dos conceptos de normalidad: la norma del valor, que apunta a identificar lo anormal con aquello que se desvíe del ideal impuesto por una ideología personal de valores, y la norma del término medio que, únicamente cuantitativa, define como anormal aquello que se aparte de lo común o frecuente. Esta última es con la que trabaja la Psiquiatría. Sin embargo, es difícil separar ambos conceptos por la imposibilidad de aplicar con rigor una delimitación cuantitativa en el área de lo psíquico y sustraerse, como probó Edmundo Mezger, de perspectivas valorativas que tengan en cuenta la cultura e ideal de hombre de la época, véase MEZGER, Edmund, Derecho penal. Parte general, Trad.: FINZI, Conrado A. y NÚÑEZ C., Ricardo C., $6^{\text {a }}$ ed., Buenos Aires: Editorial Bibliográfica Argentina, 1955, p. 62. Así, se observa y reconoce en el área de la psiquiatría en SCHNEIDER, Kurt, Las personalidades psicopáticas, $7^{\text {a }}$ ed., Madrid: Ediciones Morata, 1974, p. 31. No obstante, hay que considerar que la crítica de Mezger determinó que el concepto de normalidad de Schneider no era aplicable en los tribunales, porque según este toda forma de psicopatía debía ser tratada como una degeneración. Por ello, es difícil dejar de considerar que, posiblemente, la crítica de Mezger buscó vincular la personalidad psicopática a las actividades eugenésicas de la Alemania de la época, BERRÍOS, Germán E., Historia de los síntomas de los trastornos mentales: la psicopatología descriptiva desde el siglo XIX, México, D.F.: Fondo de Cultura Económica, 2008, p. 529. Asimismo, se disiente de la posición de Mezger en BARBERO, Natalia; SALDUNA, Mariana, "Responsabilidad penal del psicópata", Revista Latinoamericana de Derecho, año IV, n 7-8 (2007), pp. $89-127$, p. 97. 
del mismo modo que ninguna persona puede hacer alusión a la conciencia sin referirse a una experiencia personal, nos parece que esta subjetividad en el miedo insuperable está irremediablemente conectada con el mundo exterior; es decir, a un aspecto objetivo. ${ }^{49}$

Nos parece que el miedo insuperable atiende a un análisis que combina tanto aspectos subjetivos como objetivos, debiendo acreditar, si queremos aplicar la eximente, encontrarnos ante una perturbación grave que, siguiendo los parámetros de la jurisprudencia, implique una alteración de la personalidad como la que presentan, según los parámetros de psicopatología, el limítrofe o borderline, el paranoico, el orgánico fronterizo y el esquizotípico. ${ }^{50}$ Trastornos de la personalidad que producen una alteración del sentido de la realidad en el agente, que actúa excediendo los límites de la defensa en estado de necesidad o legítima defensa, captando la realidad de su entorno. ${ }^{51}$ La perturbación de la voluntad en el miedo insuperable se contrapone a un trastorno metal de la apreciación de la realidad y del juicio de la realidad. ${ }^{52}$ El primero, donde el agente también puede captar la realidad de su entorno, responde solo al campo de las llamadas atenuantes pasionales. En ellas consideramos que solo podría recurrir a la atenuante de obrar por estímulos tan poderosos que naturalmente hayan producido arrebato y obcecación (art. $11 \mathrm{~N}^{\circ} 5$ ), porque es la única que requiere de una perturbación en el ánimo del agente. ${ }^{53}$ Así, en la atenuante

49 BLEULER, Eugen, Demencia precoz. El grupo de las esquizofrenias, Buenos Aires: Editorial Paidós, 1960, p. 38; HUSSERL, Edmund, Ideas relativas a una fenomenología pura y una filosofía fenomenológica, Trad.: GAOS, José, México, D.F.: Fondo de Cultura Económica, 1962, p. 29; MAZZARELLI, Alfonso, Lecciones de psicología anormal y patológica, Santiago: Universidad Diego Portales, 2006, pp. 127-129.

${ }^{50}$ CAPPONI, Psicopatología, cit. nota $\mathrm{n}^{\circ}$ 5, p. 239.

${ }^{51}$ Los fenómenos que se enfrentan en el miedo insuperable se manifiestan como una psicología de los rendimientos. Psicología objetiva en la cual es significativa, como hecho, la exactitud de una percepción en el espacio y la estimación del tiempo, JASPERS, Psicopatología general, cit. nota $\mathrm{n}^{\circ}$ 29, p. 178. Asimismo, testear la realidad ha resultado un elemento clave para diferenciar casos de reacción de esquizofrenia crónica de organización de personalidades borderline y representa una contribución de la exploración psicoanalítica de la personalidad. Testear la realidad (Reality Testing) permite diferenciar los orígenes de la percepción y el estímulo en un nivel intrapsíquico y externo, encontrándose clínicamente reconocido por la ausencia de alucinaciones y delirios, como la capacidad del paciente de empatizar con su diagnóstico, en el contexto de su interacción social, entre otros factores, KERNBERG, Otto, Internal world and external reality, New York: J. Aronson, 1985, p. 15.

${ }^{52}$ En este sentido, en el miedo insuperable la perturbación de ánimo afecta al agente sin alcanzar la inimputabilidad, es decir, el juicio de la realidad. Sin embargo, no podemos desconocer una serie de fallos que reconocen casos de inimputabilidad en el miedo insuperable haciendo caso omiso de la doctrina. Cabe destacar la Sentencia de la Corte de Apelaciones de Chillán del 10 de mayo de 1954. En esta sentencia podemos identificar que la Corte determinó, considerando el informe médico de los psiquiatras que sostuvieron que la procesada padecía un trastorno mental profundo provocado por un terror patológico y epilepsia estriada, "forzoso concluir que al asesinar a su marido mientras dormía [la acusada] se encontraba en un período de locura transitoria, que la exime de responsabilidad criminal, por lo que concurren en su favor las circunstancias de inimputabilidad criminal de los números $1^{\circ}$ y $9^{\circ}$, del art. 10 del CP", Sentencia de la Corte de Apelaciones de Chillán del 10 de mayo de 1954, RDJ, t. LII, 1955, secc. cuarta, p. 211. Énfasis añadido. Jurisprudencia que considera el miedo insuperable dentro de una causal de inimputabilidad (trastorno mental transitorio o privación temporal de la razón) se observa en Sentencia de la Corte de Apelaciones de Valparaíso, 10 de octubre de 1919, GT, s. 193, p. 792; Sentencia de la Corte de Apelaciones de Concepción, 16 de julio de 1947, GT, 1947, s. 83, p. 437; Sentencia de la Corte Suprema, 11 de octubre de 1967, RDJ, t. LXII, 1965, secc. cuarta, p. 294.

${ }^{53}$ MERA, Jorge, "Comentario al art. 11 N 5 del Código Penal”, en: COUSO SALAS, Jaime; HERNÁNDEZ BASUALTO, Héctor (Dirs.), Código Penal Comentado. Parte General. Doctrina y jurisprudencia, Santiago, AbeledoPerrot-LegalPublishing, 2011, pp. 287 y 292; NOVOA MONREAL, Eduardo, Curso de Derecho 


\section{Polít. Crim. Vol. 14, № 28 (Diciembre 2019), Art. 2, pp. 54-94.}

[http://politcrim.com/wp-content/uploads/2019/10/Vol14N28A2.pdf]

en cuestión se puede dar un trastorno de apreciación de la realidad que no afecta el sentido de esta. ${ }^{54}$ Tal afirmación la sustentamos en el hecho de que la atenuante del art. $11 \mathrm{~N}^{\circ} 5$ requiere, al igual que el miedo insuperable, de un estímulo objetivo lícito o ilícito que provoque en el agente una perturbación que dé lugar al arrebato u obcecación. ${ }^{55}$ Posición que tendría lugar tanto en el art. $11 \mathrm{~N}^{\circ} 5$ como en el miedo insuperable, porque ambas disposiciones requieren de una perturbación vinculada a la existencia de un mal o estímulo poderoso. No obstante, no debemos dejar de tomar en cuenta que la entidad de la perturbación que comprendería esta atenuante, sea desde la perspectiva de un trastorno de apreciación o sentido de la realidad, proviene de un estímulo lícito o ilícito y la eximente del miedo insuperable, de la intención de evitar un mal equivalente a un estímulo lícito.

A nuestro juicio, desde la estructura del miedo insuperable no es posible contemplar estímulos ilícitos porque se requiere de una situación de peligro real (interna o externa) que genere en el agente la decisión de ejecutar la acción defensiva. Es decir, de una acción relevante en términos de tipicidad que coloca en peligro intereses penalmente salvaguardados para resguardar otros intereses legítimos. Esta advertencia hace evidente, junto con el grado de perturbación que sufre el agente, la falta de exigencia de subsidiariedad y proporcionalidad propias del estado de necesidad. De este modo, considerando la entidad de las perturbaciones que comprende el arrebato u obcecación, nos parece que en el campo de la imputabilidad disminuida, prescindiendo de la objetividad del estímulo lícito o ilícito, estas pueden tener el mismo efecto que el de una perturbación propia del miedo insuperable. Esto, en caso de estar en presencia de un trastorno mental que afecte el sentido y no la apreciación de la realidad; de lo contrario, el efecto de graduación de la pena no debería ser más favorable al imputado. Así, consideramos que la perturbación del miedo interfiere en la atenuante de arrebato u obcecación, porque esta atenuante, al comprender estímulos lícitos, da lugar a una interpretación amplia que tiene correlación con la exigencia de evitar un mal en el campo del miedo insuperable. ${ }^{5}{ }^{5}$

Penal chileno. Parte General, t. II, $3^{\text {a }}$ ed., Santiago: Jurídica de Chile, 2005, p. 26. En este contexto, existen otras atenuantes denominadas pasionales contempladas en el $\mathrm{N}^{\circ} 3$ y $\mathrm{N}^{\circ} 4$ del art. 11 del CP. Sin embargo, estas solo exigen sus presupuestos objetivos para dar lugar a su aplicación, con independencia de alguna perturbación anímica en el sujeto, véase CURY, Enrique, Derecho Penal, cit. nota n 16, p. 480. Por otra parte, también se estudia en la doctrina chilena la posibilidad de incorporar la doctrina de la provocación en la atenuante de arrebato y obcecación, en caso de homicidios iracundos, en una línea conativa y cognitiva, en MAÑALICH, Juan Pablo, “¿Arrebato y obcecación pasionalmente condicionados como atenuante por un femicidio frustrado?", Revista de Estudios de la Justicia, no 25 (2016), pp. 245-258, p. 253 - 256.

${ }^{54}$ CAPPONI, Psicopatología, cita n ${ }^{\circ}$ 5, p. 239.

55 Sustentan esta afirmación solo en lo que respecta al arrebato u obcecación, NOVOA, Eduardo, Curso de Derecho Penal, cit. nota ${ }^{\circ}$ 53, p. 26; ETCHEBERRY, Alfredo, Derecho Penal, t. II, $3^{\mathrm{a}}$ ed., Santiago: Jurídica de Chile, 1998, p. 21; CURY, Derecho Penal, cit. nota ${ }^{\circ}$ 16, p. 487; GARRIDO MONTT, Mario, Derecho Penal. Parte general, t. I, $4^{\mathrm{a}}$ ed., Santiago: Jurídica de Chile, 2007, pp. 191-192; POLITOFF y ORTIZ, Texto y comentario del Código Penal Chileno, cit. nota ${ }^{\circ} 48$, p. 176. Objetividad en la apreciación de la atenuante del art. $11 \mathrm{~N}^{\circ} 5$ que es posible de contrarrestar por medio de la imputabilidad disminuida, véase NOVOA, Curso de Derecho Penal, cit. nota ${ }^{\circ}$ 53, p. 27; CURY, Derecho Penal, cit. nota ${ }^{\circ} 16$, p. 487 ${ }^{56}$ En esta línea, somos partidarios, en el arrebato u obcecación, de considerar que hay ciertas alteraciones que solo perturban a un grupo reducido de personas por perversiones que no les han permitido desarrollar una capacidad de inhibición como en el resto de los ciudadanos. Por ello, el arrebato u obcecación de un fetichista o sadomasoquista no es suficiente para la aplicación de la eximente. De este modo, si bien observar a una mujer desnuda puede inducir a un individuo a violarla, porque su control inhibitorio no se encuentra correctamente desarrollado, esta es una situación que no se condice con la reacción del hombre medio. El 
En el caso de que un estímulo ilícito en el arrebato u obcecación provoque la reacción del agente, no puede establecerse una relación con el miedo insuperable, aunque esta reacción se encuentre perturbada por un trastorno de apreciación o sentido de la realidad. El miedo solo se relaciona a un estímulo lícito; es decir, a un mal grave que se pretende evitar. Una posición favorable a esta interpretación se observa en la misma jurisprudencia. Así, la sentencia de la Corte de Apelaciones de Santiago, contra Hugo Rodríguez Jara, del 9 de septiembre de 1950, estableció que haber obrado por la pasión no es suficiente para configurar la coacción psíquica que requiere el miedo insuperable. No obstante, puede "admitirse que dichos hechos constituyen la causal de atenuación de la pena de haber obrado el hechor por estímulos tan poderosos que naturalmente le han producido arrebato y obcecación". ${ }^{57}$ Consideración que resulta complementada por el razonamiento de la sentencia de la Corte de Apelaciones de Santiago, contra González Díaz, Miguel Abraham, del 8 de junio de 1963. En dicha sentencia la Corte estableció que:

"los requisitos que exige la eximente del $\mathrm{N}^{\circ} 9^{\circ}$ del artículo 10 del citado Código tienen un carácter absoluto que no admite graduación y por lo mismo, no puede darse su concurrencia incompleta". ${ }^{5}$

Así las cosas, frente a un miedo o perturbación del ánimo, ante un estímulo externo o mal real, solo se podría aplicar la atenuante del art. $11 \mathrm{~N}^{\circ} 5$, si la defensa logra comprobar la presencia de una perturbación que constituya de un trastorno de apreciación de la realidad incidió al momento de ejecutar el hecho. El hecho de que las perturbaciones del arrebato u obcecación y el miedo insuperable indiquen también una apreciación objetiva ante el estímulo que lo provoca, radica en que los diferentes trastornos mentales del sentido de la realidad que comprenden no afectan el juicio de realidad. Pese a estar perturbado, el agente es capaz de comprender su entorno, aunque actúe de forma desproporcionada frente a las condiciones del estímulo externo. Pues bien, aunque la apreciación del estímulo (lícito/ilícito) o mal sea objetiva, cabe la posibilidad de que estos elementos sean imaginarios. De tal modo, frente a un estímulo o mal imaginario deberemos regirnos analógicamente por las reglas del error del art. 1 inc. 3 del CP. ${ }^{59}$

A todo lo expuesto debe añadirse que Novoa, frente el apremio de la extrema miseria, señaló que este fenómeno podría ser tratado como una eximente incompleta del estado de necesidad de no darse todas las exigencias del art. $10 \mathrm{~N}^{\circ} 7$. Estas situaciones de extrema miseria podrían ser valoradas como una atenuante de arrebato u obcecación, en el caso de aquella madre que da muerte a sus hijos por sus lamentos de hambre, o una eximente

arrebato u obcecación debe responder a un estímulo externo objetivo que provoque en el individuo una alteración en el control de sus actos o que lo afecte en su normal discernimiento, CURY, Derecho Penal, cit. nota ${ }^{\circ}$ 16, p. 487; ETCHEBERRY, Derecho Penal, cit. nota ${ }^{\circ}$ 55, p. 21. Ello, independiente del hecho de que la doctrina mayoritaria acepte incorporar estímulos ilícitos en esta eximente, véase MERA, Jorge, "Comentario al art. $11 \mathrm{~N}^{\circ} 5$ del Código Penal", cit. nota n 53 , p. 382.

${ }^{57}$ Sentencia de la Corte de Apelaciones de Santiago, contra Hugo Rodríguez Jara, del 9 de septiembre de $1950, R C P$, t. XII, p. 87.

${ }^{58}$ Sentencia de la Corte de Apelaciones de Santiago, 8 de junio de 1963, RDJ, t. LX, mayo y junio, $\mathrm{n}^{\mathrm{o}} 3$ y $\mathrm{n}^{\circ}$ 4, segunda parte, secc. cuarta, considerando séptimo, p. 268.

${ }^{59}$ En este sentido, sustentan esta posición en torno al art. $11 \mathrm{~N}^{\circ}$ 5, POLITOFF y ORTIZ, Texto y comentario del Código Penal Chileno, cit. nota n 48, p. 176. 


\section{Polít. Crim. Vol. 14, No 28 (Diciembre 2019), Art. 2, pp. 54-94. [http://politcrim.com/wp-content/uploads/2019/10/Vol14N28A2.pdf]}

incompleta de miedo insuperable frente al temor no insuperable que experimenta el agente. ${ }^{60}$ El razonamiento de Novoa nos parece equivocado, porque el estímulo de la miseria en el caso del estado de necesidad genera un comportamiento racional frente a la situación de peligro; en cambio, tanto en el arrebato u obcecación como en el miedo insuperable la acción o reacción del agente responde a un sustrato o base psicológica frente a un estímulo (lícito/ilícito) o mal (estímulo lícito). ${ }^{61}$

En este orden de ideas, la divergencia entre estas disposiciones radica en que el mal del miedo insuperable requiere de una perturbación grave que trastorne al agente en su sentido de la realidad. Sin embargo, el estímulo en el arrebato u obcecación responde a una perturbación de menor gravedad que afecte al agente en su apreciación de la realidad. Criterio interpretativo que nos permite acoplarnos estructuralmente al criterio que presenta la jurisprudencia chilena que, aparentemente, no permite la coexistencia de una eximente incompleta y atenuante pasional en función de los mismos hechos. ${ }^{62}$ Asimismo, esta solución nos posibilita delimitar lo que Labatut denominó el impulso irresistible, a propósito del arrebato o la obcecación, que dependiendo de su intensidad -siempre que no sea privativo de la razón- puede llegar a dar lugar al art. $10 \mathrm{~N}^{\circ} 9 .{ }^{63}$ Por ello, consideramos que pese a existir la posibilidad, teóricamente, de aplicar una eximente incompleta del miedo insuperable del art. $10 \mathrm{~N}^{\circ} 9$, debe primar por especialidad el art. $11 \mathrm{~N}^{\circ} 5 .^{64}$

Por otra parte, en un trastorno del juicio de la realidad — propio de la inimputabilidadexiste un compromiso estructural de la conciencia. El agente puede quedar subsumido en el delirio. ${ }^{65} \mathrm{La}$ afectación que se produce del principio de la realidad es grave concurriendo

\footnotetext{
${ }^{60}$ NOVOA, Curso de Derecho Penal, cit. nota $n^{\circ}$ 53, p. 27.

${ }^{61}$ El estado de necesidad desde esta perspectiva sufriría una caracterización psicológica cuestionable en el estado de necesidad exculpante e inaceptable en el estado de necesidad justificante, véase WILENMANN, "El fundamento del estado de necesidad justificante", cit. nota ${ }^{\circ} 31$, p. 244, nota 23; FIANDACA, Giovanni y MUSCO, Enzo, Derecho penal. Parte general, Trad.: NIÑO, Luis Fernando, Bogotá: Temis, 2006, pp. 302 y ss.; CURY, Enrique, "El estado de necesidad en el Código Penal Chileno", en: MAÑALICH, Juan Pablo (Coord.), La Ciencia Penal en la Universidad de Chile. Libro homenaje a los profesores del Departamento de Ciencias Penales de la Facultad de Derecho de la Universidad de Chile, Santiago: Universidad de Chile, 2013, p. 258.

${ }^{62}$ ORTIZ QUIROGA, Luis y ARÉVALO CUNICH, Javier, Las consecuencias jurídicas del delito, Santiago: Jurídica de Chile, 2013, p. 382; MERA, Jorge, “Comentario al art. $11 \mathrm{~N}^{\circ} 5$ del Código Penal”, cit. nota ${ }^{\circ} 53$, p. 295. En este contexto, la Corte Suprema estableció que la atenuante del art. $11 \mathrm{~N}^{\circ} 5$-obrar por estímulos poderosos que produjeron arrebato u obcecación- no puede concurrir al mismo tiempo que la eximente incompleta del art. $10 \mathrm{~N}^{\circ} 1$. Este arrebato u obcecación debe ser provocado por un "estímulo externo, grave y poderoso, extraño al sujeto... cuando ya tiene mayor duración y constituye una anormalidad mental se transforma en un trastorno mental transitorio propio del art. $10 \mathrm{~N}^{\circ} 1$ ", Sentencia de la Corte Suprema, 28 de marzo de 1972, FM, marzo, 1972, $\mathrm{N}^{\circ} 160$, año XIV, considerando quinto, pp. 22-23.

${ }^{63}$ LABATUT, Derecho Penal, cit. nota n ${ }^{\circ}$ 34, p. 214; MAZZARELLI, Lecciones de psicología anormal, cit. nota ${ }^{\circ} 49$, pp. 144 y $182-183$.

${ }^{64}$ MERA, Jorge, "Comentario al art. $11 \mathrm{~N}^{\circ} 5$ del Código Penal", cit. nota n 53, p. 295.

${ }^{65}$ En este contexto, debemos tener presente que "es muy difícil definir el delirio si no existe una teoría unitaria de la psicosis, a nivel del género y su subdivisión en especies, con criterios subordinados. Aplicando nuestra teoría, definimos delirio como la afirmación y conducta de realidad, basadas en evidencias mutadas, insólitas y productivas. Lo insólito implica un cambio no esperado respecto al aprendizaje endocultural previo, o la maduración psicobiológica. Productivo se refiere a la aparición de criterios nuevos de realidad, a diferencia de un simple empobrecimiento, propio del deterioro psico-orgánico" MARCONI, Juan, "El delirio y sus estructuras psicopatológicas", Rev Chil Neuropsiquiatría 38 (2000), pp. 37-43, pp. 39 - 40.
} 
las primeras percepciones delirantes. ${ }^{66} \mathrm{El}$ agente en estos casos se encuentra privado de razón permanentemente o durante un cierto lapso (trastorno mental transitorio o estado crepuscular) al momento de ejecutar la acción. ${ }^{67}$ Contexto que es compatible con la eximente que contempla el art. $10 \mathrm{~N}^{\circ} 1$. De lo contrario, existiría una equivalencia funcional entre la inimputabilidad, el arrebato u obcecación y el miedo insuperable que haría innecesaria la referencia a estas últimas figuras. Por tanto, en el trastorno del juicio de la realidad no podemos hablar de una acción libre. En casos de grave alteración psicótica o patología no podemos imputar responsabilidad al agente. Es una zona en la que el sujeto no se puede determinar de forma libre y responsable. ${ }^{68}$ Por ello, consideramos que la libertad del agente se gradúa dependiendo del nivel de perturbación. ${ }^{69}$

\section{Pertinencia dogmática de la exigencia de una situación de impulso irresistible}

El impulso irresistible es históricamente conocido y está integrado en la tradición de la doctrina penal chilena. No así la discusión que da lugar a la problemática del impulso irresistible en la doctrina norteamericana, razón por la cual nos enfocaremos en describirla y tomar una posición. El impulso irresistible es una expresión que tiene su origen en la psicología de los impulsos y pretende determinar si el agente presentó un estado psicótico en el momento de la ejecución del hecho. Dentro del campo penal, se han pronunciado en torno a esta exigencia, pero de manera dispar, los siguientes autores: Michael S. Moore y Joel Feinberg. Ya en la aproximación de Michael S. Moore a la exigencia del impulso irresistible, se hace patente un rechazo manifiesto del impulso irresistible como fundamento de una capacidad disminuida. ${ }^{70}$

El rechazo de Moore del impulso irresistible, se remonta a la práctica que consagró la regla McNagthen (test del impulso irresistible) en el modelo americano. Pues bien, el test del impulso irresistible se enfoca solo en la falta de capacidad de control, en el momento de ejecución del hecho, según la entidad del trastorno. En esta línea, tanto el test del impulso irresistible como sus variaciones asume lo siguiente: la excusa de insanity (conocida o

${ }^{66}$ CAPPONI, Psicopatología, cit. nota n ${ }^{\circ}$ 5, p. 239.

${ }^{67}$ MAZZARELLI, Lecciones de psicología anormal, cit. nota $\mathrm{n}^{\circ}$ 49, p. 145.

${ }^{68}$ En este contexto, nos parece acertada la posición de que "la pérdida de la normal vivencia de un actuar libre y voluntario, es uno de los síntomas más graves de la patología anímica y sólo se observa en casos de profunda alienación psicótica, como ocurre, por ejemplo, en los delirios esquizofrénicos [...]", PEÑA Y LILLO, Sergio, El temor y la felicidad, Santiago: Editorial Universitaria, 1989, p. 48.

${ }^{69}$ Se debe advertir que en el fundamento de la imputabilidad existe una contraposición conceptual. Así, algunos adhieren a una posición determinista en la que la libertad se presenta como una ilusión o un indeterminismo que se resalta el libre albedrío como presupuesto de la razón. Sin embargo, nosotros asumimos la tesis de la libertad porque la enfermedad mental priva al sujeto de interactuar de forma adecuada con el medio y es un criterio no susceptible de comprobación empírica que permite vincular el Derecho penal con la psiquiatría forense. Sin embargo, este no implica diferenciar el significado de la libertad en el Derecho penal y en la Psiquiatría. En el Derecho penal la libertad tiene un sentido negativo, es decir, que la pregunta se centra en si el agente podía actuar de otro modo. En cambio, en la Psiquiatría la pregunta se enfoca en un sentido positivo, esto es, determinar si la enfermedad afecta en la conciencia del agente el sentido de la propia existencia y del contrato social. Es decir, que esta se manifiesta en el proceso de una conciencia sana, véase MARTÍNEZ, La imputabilidad penal, cit. nota n ${ }^{\circ} 3$, pp. 343 - 345.

${ }^{70}$ En sentido, se rechaza una compresión del mens rea en que la enfermedad mental admite una graduación de la responsabilidad penal en MOORE, Michael S., Law and Psychiatry. Rethinking the relationship, New York: Cambridge University Press, 1984, p. 219. 
denominada en el sistema jurídico-chileno como inimputabilidad) opera solo en el acto en particular y no es un estatus general para una clase de personas que carecen de la capacidad de reconocer la infracción de la norma. Asimismo, el test del impulso irresistible asume que la excusa de insanity está vinculada a la coacción, compulsión e ignorancia y no observan en esta una forma especial de excusa. ${ }^{71}$

Así las cosas, el impulso irresistible presenta detractores — ante el fracaso de la aplicación de la excusa de insanity como causa de inculpabilidad ${ }^{72}$ - y aceptación de las teorías psicoanalíticas de los años veinte. ${ }^{73}$ Pero la posición de rechazo del impulso irresistible, presente en la obra de Moore, nos parece ingenua e insuficiente. Las alteraciones en el trastorno de realidad son relevantes en el momento de la ejecución de la conducta, sea resultado de una falta de comprensión de la norma o la significación antijurídica de la conducta. Pues bien, la existencia de desórdenes mentales, neuróticos, entre otros, no son suficientes para explicar la conducta de quienes los padecen. Es evidente que la regla McNaghten es compatible con esta última posición, de modo que la exigencia del impulso irresistible requiere, en adelante, fundamentación.

A nuestro juicio, es suficiente apelar a la imposibilidad de determinar el trastorno que padecía el imputado en la ejecución del hecho criminal o delictivo. Pues bien, siempre debemos recrear en atención a la evidencia, en los parámetros de una verdad formal, cuáles son las hipótesis que explican la conducta del imputado. ${ }^{74}$ Asimismo, se hace manifiesto que, en consonancia con Feinberg, la exigencia del impulso irresistible exige que el agente actué en un delirio psicótico, según la regla McNagthen. Así pues, el agente únicamente es excusado si supuso que era inocente o actuó en la creencia de estar amparado en una norma permisiva. De ahí que si un hombre conjetura, en atención a un delirio psicótico, que es víctima de un ataque mortal y mata —en el supuesto de una legítima defensa - sea excusado. $^{75}$

Pero debemos ser prudentes: la regla McNaghten no hace una mera concesión con la naturaleza del trastorno que padece el agente, puesto que no es el trastorno el que excusa, sino la ignorancia que genera el trastorno en atención a los presupuestos del caso. Por ello, el prius lógico del impulso irresistible es compatible con una lógica propia de ciertas causas de exculpación. Esto favorece que el impulso irresistible sea considerado parte de la coacción, según la compulsión interna que provoca la ignorancia en el agente. Última perspectiva que supone aceptar que el impulso tiene espacio en la ignorancia o coacción a modo de excusa. ${ }^{76}$

\footnotetext{
${ }^{71}$ MOORE, Michael S., Law and Psychiatry. Rethinking the relationship, cit. nota ${ }^{\circ}$ 70, p. 219.

${ }^{72} \mathrm{Si}$ bien la expresión inculpabilidad es propia del Derecho penal continental, es importante considerarla en este contexto. Pues bien, la inculpabilidad representa a la imputabilidad como un prerrequisito del juicio de culpabilidad.

${ }_{73}^{73}$ MOORE, Michael S., Law and Psychiatry. Rethinking the relationship, cit. nota ${ }^{\circ} 70$, p. 222

${ }^{74}$ Se observa oposición en la doctrina chilena a la regla McNaghthen, en la línea de argumentación de Michael S. Moore, en PAVEZ DIEZ, Mauricio, Trastornos mentales e imputabilidad, $2^{\mathrm{a}}$ ed., Santiago: Editorial Metropolitana, 2014, pp. 36 y ss.

${ }_{76}^{75}$ MOORE, Michael S., Law and Psychiatry. Rethinking the relationship, cit. nota $\mathrm{n}^{\circ}$ 70, p. 222

${ }^{76}$ Véase FEINBERG, Joel, "What Is So Special about Mental Illness?", Doing and Deserving, Princeton: Princeton University Press, 1970, pp. $274-277$.
} 
Ahora bien, en su sentido más propio, la exigencia del impulso irresistible es una categoría más bien de la Filosofía que de la Psiquiatría o el Derecho Penal. En sus orígenes el impulso irresistible siempre ha estado conectado con la vis metus, es decir, con una coacción psicológica que impide el ejercicio de una acción perfectamente voluntaria. Pues bien, la distinción entre compulsión y coerción presenta diferentes tipos de fuerzas que limitan las opciones del agente. Así, los factores de fuerza pueden radicar en la naturaleza, condiciones personales de fobia, obsesión, entre otras fuentes internas o compulsivas. ${ }^{77}$

De ahí que la coacción mitiga o exculpa si la acción es suficientemente involuntaria para responsabilizar al perpetrador. ${ }^{78}$ Lo cual implica que en ciertos casos de necesidad sea posible la existencia de una compulsión interna (internal compulsion) ${ }^{79}$ que explique los excesos en la selección de los medios o requerimientos de la cláusula de subsidiariedad. En este sentido, no sería errado indicar que un agente puede asumir supuestos de riesgo que sean voluntarios e involuntarios. Voluntariedad que uno puede pensar en grados. Sin embargo, solo aquellas acciones en las cuales el agente está en pleno control deliberativo de sus facultades pueden considerarse dentro de la categoría de una voluntad perfecta.

A su vez, la voluntad perfecta, tampoco puede alcanzar su plenitud si el agente no está informado de cada una de las contingencias o hechos relevantes del caso y, asimismo, en ausencia de una presión coercitiva (coercive pressure). La radical perfección de la voluntariedad se encuentra en una deliberación calmada y no perturbada de emociones o compulsiones neuróticas. Así, el impulso irresistible sería una idea rectora en la graduación de los trastornos para definir cómo la extensión de la compulsión, falta de información, pensamiento alterado (en razón de sustancias psicotrópicas u otras que alteren la percepción), entre otras causas, representan una falta de voluntad perfecta o incluso un comportamiento irracional desde la inimputabilidad. ${ }^{80}$

En síntesis, la exigencia del impulso irresistible conlleva que el trastorno opere en la ejecución del hecho. El agente solo puede regirse por normas en caso de permanecer inalterada su capacidad de control en la situación que enfrenta. De donde derivan dos consecuencias metodológicas en torno a la psicología de los impulsos. Por una parte, que el impulso irresistible sea tratado desde un modelo filosófico que, en la línea de Michael S. Moore, niega la formulación del impulso irresistible debido a sus erradas suposiciones metafísicas. $^{81}$ Lo cual presupone aceptar una forma clásica de psicoanálisis que es incompatible con la fenomenología. Por otra parte, una perspectiva fenomenológica del impulso irresistible, compatible con el psicoanálisis, rechaza una perspectiva escolásticobrentaniana en el análisis de la finalidad del agente. De este modo, nos parece que solo a través de la fenomenología se ha de enfrentar el análisis del impulso irresistible. Por lo tanto, en la siguiente sección se expondrá las razones de adhesión a la fenomenológica.

\footnotetext{
77 Véase FEINBERG, Joel, "Harm to Self", The moral limits of the criminal law, vol. 3, Oxford: Oxford University Press, p. 191.

${ }^{78}$ Véase FEINBERG, Joel, "Harm to Self”, cit. nota n 78 , pp. 123 y ss.

${ }^{79}$ Véase FEINBERG, Joel, "Harm to Self”, cit. nota n $^{\circ} 78$, pp. $151-152$.

${ }^{80}$ Se puede observar un tratamiento interesante de estos factores en torno al concepto de voluntad perfecta y el reconocimiento de presiones coercitivas en FEINBERG, Joel. "Harm to Self", cit. nota no 78, p. 104.

${ }^{81}$ Véase MOORE, Michael S., Law and Psychiatry. Rethinking the relationship, cit. nota $\mathrm{n}^{\circ} 70, \mathrm{p} .422$.
} 


\section{Polít. Crim. Vol. 14, No 28 (Diciembre 2019), Art. 2, pp. 54-94. [http://politcrim.com/wp-content/uploads/2019/10/Vol14N28A2.pdf]}

\subsection{Comprensión fenomenológica del impulso irresistible}

Es indiscutible que el Derecho Penal no es Psiquiatría o Filosofía, de manera que explicar la adopción de la fenomenología como herramienta de graduación del impulso irresistible requiere fundamentación. Ya hemos constatado que, en la historia de la dogmática penal, la fenomenología aparece inicialmente con la teoría de la acción finalista de Hans Welzel, y lo hace de la mano de psicólogos fenomenólogos. ${ }^{82}$ Pero esta adhesión a la fenomenología es ingenua e insuficiente en lo que concierne a la graduación del impulso irresistible. ${ }^{83}$ No expondremos aquí esos puntos de la teoría finalista. Nos parece que la comprensión de ellos requiere primero explicitar qué entendemos por fenomenología, con el objeto de aceptar o rechazar su aplicación en el Derecho Penal. ${ }^{84}$

La fenomenología establece un método descriptivo destinado a una filosofía estrictamente científica. ${ }^{85} \mathrm{Si}$ es admisible la rigurosidad matemática o filosófica, ¿qué frena a la dogmática penal de ser científica? Resulta claro que la fenomenología requiere en la dogmática penal una vía despejada, porque si bien toda experiencia psíquica procede de la propia experiencia, ello no implica una vinculación estricta entre la voluntad del agente y su comportamiento objeto de imputación penal. ${ }^{86}$ Por ello, debemos ser cuidadoso: la acción penal para la fenomenología no es un fenómeno que pertenezca a una mera realidad empírica o conciencia individual. Pues bien, el penalista describe y analiza los presupuestos fácticos de dicha acción y los explicita en el lenguaje de su propio sistema a través de evidencia. Adecuación analítica que imprime finalidad a la acción del agente en un contexto intersubjetivo. ${ }^{87}$

\footnotetext{
${ }^{82}$ Véase supra nota 5.

${ }^{83}$ Lo expuesto en atención a la tesis de la identidad del tipo objetivo e incluso en torno a los efectos de la vencibilidad en el error, véase MAÑALICH, Juan Pablo, "La imprudencia como estructura de imputación", Revista de Ciencias Penales, Vol. XLII, N³, 2015, pp. 13-35, pp. 16-17.

${ }^{84}$ La plataforma conceptual de nuestra concepción fenomenológica se encuentra en HUSSERL, Edmund, Investigaciones lógicas, Madrid: Biblioteca Revista de Occidente, 1976, passim; HUSSERL, Edmund, Ideas relativas a una fenomenología pura y una filosofía fenomenológica, México: Fondo de Cultura Económica, 1962, passim.

${ }^{85}$ En este contexto, es importante indicar que "a fin de lograr una base inatacable para todas las ciencias [Husserl] se sirvió del método fenomenológico. Este empieza con una doble reducción: la reducción eidética prescinde por lo pronto de la existencia del yo, de los actos aprehensivos y de los objetivos, considerando la mera esencia... de estos en concreación íntegra. En la segunda, la reducción fenomenológica, es también «suspendida» la independencia de estos contenidos con respecto a la conciencia. La fenomenología considera sus objetos sólo «como» objetos (teoría del objeto), como correlativos de la conciencia. Queda así la conciencia pura, pero que no está en modo alguno vacía. Constituyen su estructura el «tener conciencia»... y «lo tenido en conciencia»". Por ello, para la fenomenología la filosofía "ha de definirse como una teoría puramente descriptiva de la esencia de las configuraciones inmanentes de la conciencia", BLUGGER S.I., Walter, Diccionario de Filosofía, Barcelona: Editorial Erder, 1975, p. 231.

${ }^{86}$ En este contexto, una noción puramente volitiva en materia penal podría presentar dificultades en la imputación jurídico-penal en el ámbito de los delitos de mera actividad o de abuso sexual, véase RAGUÉS I VALLÈS, Ramón, "Consideraciones sobre la prueba del dolo", Revista de Estudios de la Justicia, no 4 (2004), pp. 13-26, passim.

${ }^{87}$ Comprensión de la descripción y de la analiticidad de la conciencia que hemos tomado prestada y se observa en FLORES, Luis, "La Fenomenología de Husserl: Principios metodológicos y teóricos", Revista Chilena de Sociología y Antropología, $\mathrm{n}^{\circ} 4$ (1984), pp. 61 - 75, passim.
} 
El énfasis descriptivo de los fenómenos jurídico-penales puede ayudarnos en la graduación de los trastornos que inciden en el impulso irresistible. De este modo, la fenomenología delimita, diferencia y describe fenómenos fácticos, que serán introducidos en el campo de la significación según ciertas expresiones jurídicas (dolo eventual, preterintencionalidad, imprudencia, imputación, etc.). En esta línea, la fenomenología renuncia a la posibilidad empírica de acceder a la plataforma de lo mental. Pues bien, la fenomenología solo debe rendir cuenta de cada presupuesto fáctico e interpretación hipotética que surja en la imputación o ausencia de esta. Desde luego, podríamos afirmar que la dogmática penal es una ciencia de la acción fenomenológica. ¿Pero, qué es la acción fenomenológica? ¿Es una unidad interna y externa con carácter heterorreferencial que conlleva una realidad cognitiva?

Tal perspectiva cognitiva de la acción pareciera ser el punto de inicio en la graduación de intensidad del impulso irresistible. Sin embargo, el sistema cognitivo del agente debe considerase —en un plano de alteridad - como una expresión más a considerar en la imputación de una realidad heterorreferencial. Así, el ejercicio fenomenológico consiste en verificar cuáles son los medios para acceder a lo originalmente inaccesible, es decir, la propia conciencia del agente en el plano de la significación jurídico-penal. Conciencia que siempre está dirigida a algo (trascendencia) ${ }^{88}$ y en rechazo tanto del empirismo como psicologismo brentaniano. ${ }^{89}$

A continuación, intentaremos aplicar esta estructura básica de la fenomenología, a un problema específico y complejo del Derecho penal: la pérdida de contacto con la realidad. El ejercicio de las siguientes secciones consiste en entregar una respuesta a la siguiente pregunta: ¿cómo graduar el impulso irresistible? Pues bien, qué es el impulso irresistible apunta a la esencia del fenómeno. Problemática de la esencia que ha sido resuelta en las primeras secciones de este trabajo. ${ }^{90}$ Por ello, a continuación, nos enfocaremos en cómo se gradúa fenomenológicamente el impulso irresistible.

\subsection{Modelo psicopatológico estructural: función objetiva y de significado}

A pesar de la particular correlación que se observa en el sistema jurídico chileno entre los trastornos mentales y el impulso irresistible, se pone en duda el solo admitir peligros reales en el miedo insuperable ${ }^{91}$ e incluso un sector de la doctrina española rechaza esta posibilidad. ${ }^{92}$ Sin embargo, sobre esta base es que psiquiatras forenses como Witter partidarios del modelo de psicopatología estructural del Luthe - sostengan que solo la

\footnotetext{
${ }^{88}$ Extensión de la conciencia hacia el objeto que se denomina trascendencia en la fenomenología, véase OJEDA, César, La tercera etapa, cit. nota ${ }^{\circ} 5$, p. 44.

${ }^{89}$ En esta línea, Husserl rechaza todo cartesianismo brentaniano que sea adoptado en el tratamiento de la intención o lecturas puramente psicológicas que aspiran a probar empíricamente el acceso a la dinámica de los procesos mentales, véase GARCÍA-BARÓ, Miguel, Fenomenología y hermenéutica, España: Editorial Bonallertra Alcompas, 2015, p. 56, p. 58, p. 60, p. 62, p. 63 y p. 68. Por ello, nuestra perspectiva fenomenológica sería incompatible con lecturas filosóficas como las que se presenta en FRANKFURT, Harry, Demonds, Dreamers and Madmen: The Defense of Reason in Descartes`s Meditations, Princeton: Princeton University Press, 2007, passim.

${ }^{90}$ Respecto de la esencia del impulso irresistible, véase, supra secc. 2 y 3 de este artículo monográfico.

${ }^{91}$ MAÑALICH, Juan Pablo, "El estado de necesidad exculpante", cit. nota $n^{\circ} 16$, p. 742, entre otros.

${ }^{92}$ CUERDA, El miedo insuperable, cit. nota ${ }^{\circ} 31$, p. 125 , entre otros.
} 


\section{Polít. Crim. Vol. 14, № 28 (Diciembre 2019), Art. 2, pp. 54-94. [http://politcrim.com/wp-content/uploads/2019/10/Vol14N28A2.pdf]}

inimputabilidad supone pérdida de contacto con la realidad. En otras palabras, la inimputabilidad es el único caso en el que la enfermedad condiciona el acto de percepción y existe la posibilidad de aceptar males imaginarios que expliquen la conducta del agente.

Así las cosas, Witter diferencia dos procesos de experiencia que deben estar en equilibrio para identificar ausencia de enfermedad. El primero es denominado función objetiva (Beudeutungsfunktion) y el segundo función de significado (Gegenstandsfunktion). ${ }^{93}$ Procesos que, en correlación con el modelo de Helmut Frister, facilitan la graduación normativo-empírica de los trastornos mentales. ${ }^{94}$ El trastorno mental de mayor intensidad genera un desequilibrio en estas funciones y en consecuencia una pérdida de contacto con la realidad. Por ello, si bien el miedo insuperable contempla un trastorno mental, este no conlleva una pérdida de contacto con la realidad, es decir, que no tiene la entidad suficiente para condicionar el acto de percepción del agente. Por tanto, el peligro imaginario en casos de miedo insuperable es parte del error de prohibición.

Conforme con lo anterior, la imputabilidad responde a un fenómeno empírico-normativo en el que convive el juez y el perito. ${ }^{95}$ Así, la intervención del primero se centra en determinar cómo el perito llegó a formular su diagnóstico. Por ello, todo informe pericial requiere de un componente valorativo para determinar el grado de deterioro que presenta el agente. En esta línea, autores como Witter y Luthe consideran que pericialmente se puede acreditar la ausencia de imputabilidad. Sin embargo, la imputabilidad disminuida sería una tarea propia del juez en la cuantificación de la culpabilidad. ${ }^{96}$ De ahí que estos diagnósticos sean valoraciones que no se desprenden de "fórmulas matemáticas o análisis químicos, sino efectuando una valoración de la gravedad [del] estado mental del sujeto". 97 Por ello, lo preocupante no es el pronunciamiento pericial sobre el grado de perturbación que incide en el comportamiento del agente, sino que el juez asuma como cierto dicho diagnóstico. Ello, sin someterlo a los parámetros normativos enunciados. Tratamiento estructural de la enfermedad no deja de vincular el trastorno mental con el hecho delictivo cometido, es decir, con los motivos por los cuales se ejecutó. ${ }^{98}$ El juez ha de facilitar la valoración de

\footnotetext{
${ }^{93}$ Véase LUTHE, Rainer, «Schuldfähigkeit-ein rationales Mittel sozialer Regulation?», SchwZStr 103 (1986), pp. 345 -366, passim; WITTE, Hermann, Unterschiedliche Perspektiven in der allgemeinen und in der forensischen Psychiatrie. Eine kleine Methodenlehre für Juristen, psychologisch-psychiatrische Sachverständige und interessierte Laien, Berlin: Springer, 1990, p. 76 y ss.

${ }^{94}$ Véase MARTÍNEZ, La imputabilidad penal, cit. nota ${ }^{\circ}$ 3, p. 323.

${ }^{95}$ En este contexto, no podemos desconocer que la relación que existe entre la imputabilidad (capacidad de obrar de obrar en conformidad a lo que dispone el ordenamiento jurídico-penal) y la exigibilidad (concreación de la capacidad de obrar de otro modo según las condiciones internas y externas del autor). Por ello, la exigibilidad si bien responde a un parámetro concreto, la imputabilidad reconoce un campo interno y externo en el ejercicio de la conducta, véase MELENDO PRADOS, Miguel, El concepto material de culpabilidad y el principio de inexigibilidad, Granada: Editorial Comares, 2000, p. 260, p. 388 y p. 411. Por ello, consideramos que es posible observar en el miedo insuperable trastornos que incidan en los excesos que pueda presentar el estado de necesidad o la legítima defensa.

${ }^{96}$ WITTE, Hermann, Unterschiedliche Perspektiven, cit. nota $\mathrm{n}^{\circ} 93$, p. 76 y ss.

${ }^{97}$ MARTÍNEZ, La imputabilidad penal, cit. nota ${ }^{\circ}$ 3, p. 294.

${ }^{98}$ RASCH, Wilfried, Forensische Psychiatrie, $2^{\mathrm{a}}$ ed. revisada y ampliada, Stuttgart: Kohlhammer, 1999, pp. 186 y ss.
} 
dicha motivación para estimar — a través de consideraciones ajenas a la ciencia de la psiquiatría o psicología — la posibilidad de exculpar o atenuar la responsabilidad penal. ${ }^{99}$

En este contexto, la posible superposición de la función del juez y el perito se puede evitar delimitando el espacio del informe pericial. Para lograr este objetivo, debemos considerar que el perito solo se pronuncia en torno a la gravedad del trastorno mental y cómo incide en el comportamiento del agente. De ahí que la tarea de la dogmática esté enfocada en entregar un criterio normativo que permitan identificar los factores psíquicos que inciden en la imputabilidad $^{100}$. Por ello, adquiere sentido aceptar la función objetiva y de significado en la comprensión del impulso irresistible. Con estas funciones se pone de relieve cómo la diferenciación entre acto perceptivo e imaginario constituyen algo más que una mera enunciación empírica. Es sobre todo una muestra de que, en cuanto a los efectos de la inimputabilidad $\mathrm{u}$ otras causales de inexigibilidad, los intereses de la dogmática atienden a la práctica cotidiana del proceso. Así, la pretensión de una mayor estabilidad en la interpretación debe extender sus efectos a las funciones enunciadas, que se encuentran condicionadas por el desarrollo dogmático de Frister, y el modelo psicopatológico estructural. Concretamente, más allá de las discusiones en torno a la conveniencia de este modelo psicopatológico estructural, el sistema jurídico penal chileno aún no logra solucionar esta problemática, y que exige, por tanto, una mayor delimitación.

A continuación desarrollaremos el elemento objetivo del miedo insuperable. Es decir, la problemática de la realidad del mal en conformidad a los parámetros a la función objetiva y de significado del modelo psicopatológico estructural.

\section{Autorreferencialidad y heterorreferencialidad en el miedo insuperable}

\subsection{Parámetros dogmáticos de la realidad como fenómeno intersubjetivo}

La problemática de contemplar un mal real e irreal en el miedo insuperable nos parece relevante en el miedo insuperable porque pone a prueba su fundamento. ${ }^{101}$ En este contexto, los consensos alcanzados en dogmática y jurisprudencia muestran que la realidad del mal es intersubjetiva y que se debe analizar para compréndelo. ${ }^{102}$ Sin embargo,

\footnotetext{
${ }^{99}$ Sin embargo, es importante indicar que en el trastorno mental transitorio o en los casos de síndrome de abstinencia es importante considerar que los elementos cognitivos y afectivos del proceso de motivación deben ser tratados a nivel psicológico y el resto desde los parámetros de la valoración jurídico-penal, véase MARTÍNEZ, La imputabilidad penal, cit. nota $n^{\circ} 3$, p. 350.

${ }^{100}$ En este contexto, calificamos nuestra interpretación como fenomenológica, es decir, como propia de una tradición que no desconoce el sustrato físico-psíquico o antropológico del agente en materia de imputabilidad Así, nos parece que "la imputación subjetiva no puede descuidar, por enérgico normativismo que se profese... la forma en que tomamos nuestras decisiones y procesamos nuestros conocimientos al momento de actuar", PIÑA ROCHEFORT, Juan Ignacio, "Conocimiento y Sistema cognitivos. Algunas alteraciones sobre la imprudencia”, Revista de Ciencias Penales, Sexta ÉPOCA, Vol. XLII, N 3, (2015), pp. 37- 60. p. 57.

${ }^{101}$ Véase CEREZO MIR, José, Curso de Derecho penal español. Parte general, t. III, Madrid: Tecnos, 2001, p. 864.

${ }^{102}$ Intersubjetividad que también puede incidir en la determinación de la imputabilidad al menos en "la realidad intersubjetiva formada por las representaciones sobre el mundo, los modos de pensamiento y las relaciones de sentido expresadas en el lenguaje, que compren los seres humanos de una cultura y momento histórico determinado", MARTÍNEZ, La imputabilidad penal, cit. nota n 3, p. 357.
} 


\section{Polít. Crim. Vol. 14, № 28 (Diciembre 2019), Art. 2, pp. 54-94. [http://politcrim.com/wp-content/uploads/2019/10/Vol14N28A2.pdf]}

debemos ir más allá de estos consensos para no caer en un ontologisismo débil que se sostenga solo en posiciones dominantes en el miedo insuperable. ${ }^{103}$ Todas las situaciones de miedo insuperable toman lugar bajo ciertas circunstancias concretas. Ciertamente, podríamos suponer que todo estímulo provoca una reacción. Pero en la vida real se presentan situaciones marginales en las que el peligro pone en riesgo intereses o situaciones en las cuales la experiencia humana nos recuerda lo que el hombre es y puede llegar a ser. ${ }^{104}$ Así, el análisis del comportamiento del agente depende de la noción de conducta, pero también de las normas jurídico-penales que se consideren en juego. ${ }^{105}$ Pues bien, existe una realidad empírica que puede ser objeto de representación dogmática en este consenso intersubjetivo. ${ }^{106}$ Por ello, es posible incorporar categorías que provienen de una fenomenología filosófica de la psiquis del sujeto, para explicar la situación que se presenta jurisprudencialmente en el miedo insuperable. ${ }^{107}$

103 SILVA SÁNCHEZ, Jesús María, Perspectivas sobre la política criminal moderna, Buenos Aires: Depalma, 1998, p. 44.

${ }^{104}$ JASPERS, Psicopatología general, cit. nota n² 29, p. 326.

${ }^{105} \mathrm{La}$ realidad requiere de un cierto grado de consenso respecto de lo que entendemos por ella. Para poder analizar un comportamiento, debemos separarnos de lo que el agente acepta como una realidad concreta y de lo que nosotros mismos consideramos que debería ser esta, JASPERS, Psicopatología general, cit. nota ${ }^{\circ}$ 29, p. 326. Así pues, en casos de imputabilidad disminuida "se habrá de exigir básicamente que la constitución psíquica del sujeto se aparte claramente de la media de la normalidad y se aproxime a la inimputabilidad", ROXIN, Claus, Derecho penal. Parte general, t. I., Trad.: LUZÓN PEÑA, Diego, $2^{\mathrm{a}}$ ed., Madrid: Civitas, 1997, p. 84. Contexto en el que no es posible ofrecer un valor estandarizado, excepto en situaciones de embriaguez. Por lo tanto, consideramos que se puede desprender un parámetro de graduación de la afectación psíquica por medio de las categorías de una psicología fenomenológica. Categorías atingentes a un trastorno del juicio de la realidad, trastorno del sentido de la realidad y trastorno de apreciación de la realidad que permiten un vínculo con la perturbación del ánimo no solo concerniente a la imputabilidad disminuida, sino también propia del miedo insuperable.

${ }^{106}$ También se reconoce la "realidad intersubjetiva [...] constituida por las normas penales" en lo que concierne a la problemática de la imputabilidad en MARTÍNEZ, La imputabilidad penal, cit. nota $\mathrm{n}^{\circ} 3$, p. 357, p. 358.

${ }^{107}$ Se puede observar un trabajo dogmático en el modelo jurídico español que reconoce el carácter de ciencia coadyuvante de la Psiquiatría, en URRUELA MORA, Asier, Imputabilidad Penal y anomalía o alteración psíquica. La capacidad de culpabilidad Penal a la luz de los modernos avances en psiquiatría y genética, Bilbao-Granada: Comares, 2004, pp. 193-197. No obstante, esta obra presenta una lectura del fenómeno especialmente relacionada con la clasificación de los trastornos del DSM-IV y la CIE-10 de la Organización Mundial de la Salud que nos parece parcialmente correcta. Si bien se deben considerar estos manuales, la realidad empírica de ellos es dinámica. La propuesta del autor no podrá adaptarse a los cambios si no logra un plano de abstracción analítico que sea capaz de identificar las propiedades intrínsecas de la percepción de la realidad en el agente, GHIRARDI, Olsen A., Lecciones de lógica del Derecho, Córdoba: Universidad Nacional, 1982, pp. 30-31. Ciertamente, sobrepasa las capacidades del dogmático tratar la problemática desde un ámbito puramente psicológico. Tarea que corresponde a la Psiquiatría o Psicología. Con todo, creemos que nuestro objetivo debe centrarse en afrontar de forma crítica desde la filosofía jurídico-penal la decisión del agente en situaciones de peligro o agresión ilegítima. Ello, sin dejar de reconocer en este la presencia de un impulso irresistible que no le permite cumplir con las exigencias de las reglas de comportamiento, según la opinión de la doctrina mayoritaria en el ámbito nacional, véase HERNÁNDEZ, "Comentario al art. $10 \mathrm{~N}^{\circ} 9$ del Código Penal", cit. nota n ${ }^{\circ} 23$, p. 253. Punto de partida que se reconoce en la formulación de una teoría de la libertad de la voluntad, en la actual doctrina filosófica del Derecho penal, en ENGISCH, Karl, La teoría de la libertad de la voluntad en la actual doctrina filosófica del Derecho penal, Trad.: GUZMÁN DALBORA, José Luis, Valparaíso: Edeval, 2006, p. 89. 
Esta realidad empírica, que exhibe la Psiquiatría al Derecho penal, es una función meramente instrumental que opera en función consultiva del juez. Función de valoración que se desarrolla en el marco del sistema procesal. El criterio de apreciación de la prueba no implica en el sistema chileno solo acoger el conocimiento científicamente afianzado que puede aportar la Psiquiatría, sino también los principios de la lógica y las máximas de la experiencia. Así, el aporte de esta disciplina se compone de un diagnóstico de la alteración psíquica y de la valoración de la gravedad del diagnóstico. Valoración que se realizará en atención al grado de pérdida de contacto con la realidad que padece el agente al ejecutar el hecho. Es decir, que el juez debe valorar "en qué medida ese alejamiento de la realidad supone una desviación suficiente delo que se considera normal como para merecer un trato distinto por parte del Derecho penal". ${ }^{108}$

Si bien determinar la presencia de un trastorno mental en el agente compete a la psiquiatría o psicología jurídica, el definir sus efectos en la comprensión del comportamiento delictivo y el control de la conducta es una función normativa, que corresponde al juez, y que no se funda únicamente en los conocimientos científicos de la psiquiatría o psicología. Así, constituye una valoración jurídica el explicar cómo incide el trastorno mental en la compresión del hecho delictivo y en la capacidad de dirigir la conducta conforme a la norma. Con todo, el incorporar categorías que proceden de una ciencia auxiliar como la Psicopatología preocupa a la dogmática penal, porque para un sector importante el solo hecho de presentar un informe psiquiátrico que acredite la patología psíquica, aunque el agente no la padezca, sería suficiente para exculpar su comportamiento. Situación que podría constituir un medio para evadir el control social que el Derecho penal pretende imponer. ${ }^{109}$ Sin embargo, en el miedo insuperable no considerar la exigencia de la realidad del mal, tomando en cuenta la función auxiliar de la Psiquiatría, genera un problema aún mayor en la evasión del control. Pues bien, en esta eximente solo se pueden considerar una serie de trastornos mentales o patologías que no privan al sujeto de su juicio de realidad. ${ }^{110}$

\footnotetext{
${ }^{108}$ MARTÍNEZ, La imputabilidad penal, cit. nota $\mathrm{n}^{\circ}$ 3, p. 358.

109 Véase STRATENWERTH, Günter, El futuro del principio jurídico penal de culpabilidad, Madrid: Publicaciones del Instituto de Criminología de la Universidad Complutense de Madrid, 1980, p. 99; URRUELA, Imputabilidad Penal y anomalía o alteración psíquica, cit. nota $\mathrm{n}^{\circ} 107$, p. 197. Por otra parte, no podemos desconocer que existen esfuerzos en la dogmática por tratar de identificar, en el plano de la inimputabilidad e imputabilidad disminuida, cuáles son los síndromes o patologías mentales que podrían albergar tales figuras jurídicas, véase JOSHI JUBERT, Ujala, Anomalía y alteración psíquica en el Código Penal español, Madrid: Grupo Difusión Jurídica, 2009, passim; JIMÉNEZ DÍAZ, María José; FONSECA MORALES, Gema María, Trastornos de la personalidad (psicopatías). Tratamiento científico y jurisprudencial, $2^{\mathrm{a}}$ ed., Madrid: CESEJ-Ediciones Madrid, 2007, passim; FONSECA MORALES, Gema María, La anomalía o alteración psíquica como eximente o atenuante de la responsabilidad criminal, Madrid: Dykinson, 2009, passim; CORCOY BIDASOLO, Mirentxu y MIR PUIG, Santiago, Comentarios al Código Penal. Reforma LO 5/2010, Valencia: Tirant lo Blanch, 2011, pp. 77-82; FULFORD, K.W.M., "Value, Action, Mental Illnes and the Law", en: SHUTE, Stephen, et al. (Ed.), Action and value in criminal law, Oxford: Clarendon Press, 1996, pp. 279-310.

${ }^{110}$ Por ello, nos parece fundamental determinar cuándo la realidad del mal podría dar lugar a dicha evasión del control; en otras palabras, cuando no existe la presencia de un peligro que nos permita hablar del miedo insuperable en sentido diverso de la inimputabilidad total o disminuida. La imputabilidad disminuida permitiría comprender todos aquellos casos en que no habría un trastorno en los cuales no existe un peligro para el agente. En este contexto, si bien nuestro ordenamiento no la contempla de forma expresa, son pioneros en su reconocimiento el CP alemán de 1971 y el CP italiano de 1889, debido a los avances de la Psiquiatría, véase URRUELA, Imputabilidad Penal y anomalía o alteración psíquica, cit. nota $\mathrm{n}^{\circ}$ 107, p. 185; POZO
} 
La consecuencia de esta relación entre el miedo insuperable y las ciencias de la psiquis es indudable. Lo que queda por solucionar es si, además de esta pretensión normativa de graduación de los trastornos mentales, puede encontrarse un criterio jurídico con arreglo al cual pueda determinase si los estímulos tienen vinculación con el trastorno mental que padece el agente. Si bien Figueiredo Dias dogmáticamente-siguiendo el modelo de Mezger - se encarga de resaltar a la comprensibilidad como un criterio normativo en estos casos, no establece cuáles son los parámetros para diferenciar si el agente comprende las consecuencias de su acción en el plano de la imputabilidad o el miedo insuperable. ${ }^{111}$ Por ello, en nuestra propuesta se presenta una vinculación radical entre el juicio de comprensibilidad social y la perspectiva psiquiátrica y psicológica forense. Si bien el juicio de comprensibilidad se caracteriza por su vaguedad, nosotros buscamos adoptar un criterio "psicopatológico objetivo, susceptible de ser aplicado a cualquier tipo de trastorno". 112

En definitiva, la comprensión de la percepción de la realidad requiere en el campo jurídicopenal de parámetros extra-normativos pero también otros de índole normativo. En consecuencia, el contenido de la disposición del miedo insuperable está más allá de lo que indica el art. $10 \mathrm{~N}^{\circ} 9$, y nos parece que si el Derecho penal quiere mantener un grado de conexión con el proceso, no puede contradecir la constatación jurisprudencial y dogmática de la graduación de los trastornos. Así, los operadores del sistema requieren de un anclaje conceptual que le permita reconocer (normativamente) la realidad jurisprudencial, ${ }^{113}$ según los parámetros que se expondrá a continuación.

\subsection{Propuesta de diferenciación entre acto perceptivo e imaginario}

La comprensión de qué entendemos por realidad facilita la delimitación del tipo de males que contempla el miedo insuperable. Del mismo modo que en el estado de necesidad y el miedo insuperable existe la posibilidad de un análisis heterroreferencial, también consideramos que el miedo insuperable encierra tal disyuntiva. Por ello, de lo expuesto en esta sección y en la sección anterior, podemos indicar algunas características de nuestra

SILVA, Nelson, Imputabilidad penal y mente, Santiago: ARCIS, 2010, p. 47 y p. 47, nota 70; CEREZO, Curso de Derecho penal español, cit. nota ${ }^{\circ}$ 101, p. 97; ANTÓN ONECA, José, Derecho penal, $2^{\mathrm{a}}$ ed., Madrid: Akal, 1986, pp. 361-365.

${ }^{111}$ Véase FIGUEIREDO DIAS, Jorge de, Liberdade - culpa - direitto penal, Portugal: Coimbra, 1976, pp. 220 - 223 y ss.

${ }_{112}^{112}$ MARTÍNEZ, La imputabilidad penal, cit. nota ${ }^{\circ}$ 3, p. 252.

${ }^{113}$ JAKOBS, Günther, Sobre la normativización de la dogmática jurídico-penal, Trad.: CANCIO MELIÁ, Manuel y FEIJÓO SÁNCHEZ, Bernardo, Madrid: Thomson-Civitas, 2003, pp. 44 y 53. Esta posición de Jakobs se crítica en la dogmática española porque entra "en cierta contradicción con aquellos pasajes de su obra en los que niega que realidades extranormativas deben servir de modelo para la regulación o para la construcción de conceptos penales" en MARTÍNEZ, La imputabilidad penal, cit. nota n ${ }^{\circ}$ 3, pp. 227 - 228. Sin embargo, debemos indicar que la teoría de sistemas estima que los sistemas pueden incorporar elementos externos a los mismos según su lógica binaria, con independencia de ser sistemas operacionalmente clausurados. Es decir, que el propio sistema jurídico puede incorporar elemento extra-normativos de la psiquiatría en conformidad a sus parámetros de selección. Así pues, el sistema jurídico comunicacionalmente se encuentra acoplado estructuralmente a los sistemas de conciencia, véase RODRÍGUEZ y TORRES, "Autopiesis, la unidad de una diferencia: Luhmann y Maturana", cit. nota n 9, pp. 130 - 131. De ahí que la contradicción en Jakobs nos parezca parcialmente correcta. 
diferenciación entre acto perceptivo e imaginario. Sin embargo, esta diferenciación conlleva la aceptación de dos radicales. El primero, es que si bien en la imputabilidad existe una cuestión de índole psicológico-normativa en la que es necesaria la colaboración entre jueces y peritos en la determinación de la función objetiva (Beudeutungsfunktion) y de significado (Gegenstandsfunktion), es esencial entregar un criterio preciso con arreglo al cual efectuar dicha valoración. La consecuencia de solo reconocer la importancia de enjuiciar la gravedad del trastorno — según la motivabilidad del agente - es insuficiente. El segundo, es que los auténticos problemas de la imputabilidad se observan en los casos complejos, es decir, trastornos mentales graves que no son parte de la psicosis o no están bien clasificados. De ahí que en estos casos la falta de un criterio jurídico es evidente, e indiscutible recurrir a parámetros normativos, cuyo establecimiento es función de la dogmática penal. ${ }^{114}$

A la vista de lo expuesto, generalmente, en la filosofía de Kirkegaard, como en Psicopatología, se vincula el miedo al temor de algo o un objeto presente sensorialmente. ${ }^{115}$ Sin embargo, en la dogmática se presenta una lectura amplia del miedo insuperable, relacionada con la existencia de males reales como imaginarios. Para parte de la doctrina chilena, el miedo puede tener una fuente de peligro interna (endógena) o externa (exógena). ${ }^{116} \mathrm{El}$ factor interno del peligro lleva a algunos a afirmar que en el miedo insuperable es posible considerar males imaginarios. ${ }^{117}$ Esta posición se fundamenta en el hecho de que el miedo insuperable, como la fuerza irresistible, tiene correlación con una perturbación anímica que impulsa a actuar al sujeto frente al peligro. ${ }^{118}$

\footnotetext{
${ }^{114}$ MARTÍNEZ, La imputabilidad penal, cit. nota $\mathrm{n}^{\circ}$ 3, p. 212.

115 Véase PEÑA Y LILLO, Sergio, La angustia: Antropología y Clínica, Santiago: Editorial Universitaria, 1981, p. 91. En Psicopatología esta tendencia de vincular el miedo a un objeto y la angustia a la nada es posible observarla en JASPERS, Psicopatología general, cit. nota $\mathrm{n}^{\circ} 29$, pp. 130-131. La fuente primaria de esta posición se manifiesta en la idea de que la angustia "puede compararse muy bien con el vértigo. A quien se pone a mirar con los ojos fijos en una profundidad abismal le entran vértigos. Pero, ¿dónde está la causa de tales vértigos? La causa está tanto en sus ojos como en el abismo", KIERKEGAARD, Sören, El concepto de la angustia, Madrid: Alianza Editorial, 2007, p. 118.

${ }^{116}$ En la doctrina nacional se aceptó en casos de coacción, antes de la existencia del art. $10 \mathrm{~N}^{\circ} 11$, producto de un mal grave e inminente provocado por factores endógenos, aplicar el miedo insuperable y la fuerza irresistible para dar lugar al denominado estado de necesidad exculpante, GARRIDO, Derecho Penal, cit. nota $\mathrm{n}^{\circ}$ 16, p. 317; POLITOFF, Lecciones de Derecho Penal, cit. nota $n^{\circ} 16$, pp. 339-341, entre otros. Para un mayor detalle respecto de la discusión de la presencia de factores endógenos en la fuerza irresistible, véase HERNÁNDEZ, “Comentario al art. 10 No 9 del Código Penal”, cit. nota n 23, pp. 246-248.

${ }^{117}$ En la jurisprudencia española podemos apreciar que esta tendencia de considerar solo males reales en el miedo insuperable se da hace bastante tiempo, CÓRDOBA RODA, Juan y RODRÍGUEZ MOURULLO, Gonzalo, Comentarios al Código Penal, t. I, Barcelona: Ariel, 1972, pp. 345-350; QUINTANO RIPOLLÉS, Antonio, Comentarios al Código Penal, vol. I, Madrid: Revista de Derecho Privado, 1946, p. 137. Ahora bien, NOVOA, Curso de Derecho Penal, cit. nota ${ }^{\circ} 45$, p. 565; LABATUT, Derecho Penal, cit. nota $n^{\circ} 34$, p. 149; POLITOFF, Lecciones de Derecho Penal, cit. nota $\mathrm{n}^{\circ}$ 16, p. 348 admiten, entre otros, la posibilidad de comprender males imaginarios en el miedo insuperable. Sin embargo, otro grupo de autores remitirán los casos de males imaginarios, en situaciones de miedo insuperable, a las reglas del error cuando aquel haya sido vencible, CURY, Derecho Penal, cit. nota ${ }^{\circ}$ 16, p. 458; GARCÍA SOTO, María Paulina, El estado de necesidad, cit. nota $n^{\circ} 29$, p. 347; GARRIDO, Derecho Penal, cit. nota ${ }^{\circ} 16$, p. 316; CURY "El estado de necesidad", cit. nota ${ }^{\circ}$ 61, p. 265, nota 50; en contra, POLITOFF, Lecciones de Derecho Penal, cit. nota ${ }^{\circ}$ 16, pp. 348 y ss.; PRAMBS JULIÁN, Claudio, El tipo de culpabilidad en el Código Penal Chileno, cit. nota $\mathrm{n}^{\circ} 48$, pp. 248 y ss.

${ }^{118}$ HERNÁNDEZ, "Comentario al art. 10 Nº 9 del Código Penal”, cit. nota n 23, p. 253.
} 
Pero al margen de esta posición, nos parece que el mal no deja de ser real en una situación de peligro interna o endógena. De este modo, un drogadicto bajo un síndrome de abstinencia experimenta dolor físico, taquicardia, etc. En tales condiciones él podría suplir su necesidad al robar en una farmacia la droga que necesita para no sufrir un colapso nervioso. En este caso, la situación de peligro es real y endógena en los casos de abstinencia física (Beschaffungskriminalität). Pues bien, el síndrome de abstinencia "no necesariamente conlleva un deterioro de las facultades mentales fuera de los episodios de intoxicación aguda". 119 También en un caso de hurto famélico podría presentarse una situación de peligro por inanición que genere en el agente una perturbación anímica por no comer en cuatro días. ${ }^{120}$ Caso en el cual las razones del hurto no radican en el estado de cesantía del agente o la crisis financiera del país, sino más bien en la perturbación psicológica que genera la sensación de hambre en el individuo.

En el miedo insuperable la realidad del mal no necesariamente está ligada a un objeto material del mundo externo, porque la fuente del peligro puede ser interna o externa. Esta concepción del miedo, de acuerdo a la realidad e imaginación del mal, es discutible y soporta una vaguedad que la hace confusa en la aplicación a hechos concretos. La confusión surge porque no detalla el plano en el cual se utiliza dicho criterio. En Psicología es posible identificar que la percepción puede ser fusionada con la fantasía o imaginería de recuerdos, sonidos, olores, etc. Fantasía que permite al agente recolectar recuerdos y crear una experiencia presente que es esencial a la actividad mental de una persona sana, encontrándose asociada más bien a la estabilidad emocional que a un comportamiento neurótico. ${ }^{121}$ Esta imaginería no es parte del miedo insuperable porque no afecta el grado de trastorno la percepción del agente respecto de su entorno. ${ }^{122}$ De ahí que en Psicología se sostenga que nuestra percepción del mundo es una fusión entre los hechos y la fantasía. De este modo, cuando uno compra un boleto de avión, no compra solo un papel, sino también la imagen de un avión o el lugar de destino al cual se desean llegar. ${ }^{123}$

Esta última descripción de las propiedades accidentales de la realidad, válida en el campo de la Psicología, no es relevante en el caso del miedo insuperable, porque en materia penal debemos centrarnos en el análisis del peligro que afecta al agente y en la gravedad de la perturbación que restringe su capacidad para cumplir la regla de comportamiento. ${ }^{124}$ En la

\footnotetext{
${ }^{119}$ MARTÍNEZ, La imputabilidad penal, cit. nota n ${ }^{\circ}$ 3, p. 259.

${ }^{120}$ En esta línea, la necesidad por alimento puede tener causas orgánicas que generen un dolor físico en el agente que afecten su comportamiento, SIMS, Andrew, Symptoms in the mind: an introduction to descriptive psychopathology, London: W.B. Saunders, 1995, pp. 314-315.

${ }^{121}$ Se describe este complejo fenómeno de mezcla de la percepción con la intrusión de recuerdos propios de la memoria, sonidos, olores en WILLIAM, James, The Principles of Psychology, $2^{\mathrm{a}}$ ed., Chicago: Encyclopaedia Britannica, Inc., 1990, p. 503; SIMS, Symptoms in the mind, cit. nota $\mathrm{n}^{\circ} 120$, p. 78.

${ }^{122}$ Respecto de la percepción es necesario indicar que el agente debe ser capaz de diferenciar su propia existencia del objeto externo que percibe. Ello, excluye desórdenes de percepción. Pues bien, en la alucinación no existe un estímulo objetivo, pero eso no implica que el agente pueda sentir la presencia de este aunque no exista, WILLIAM, The Principles of Psychology, cit. nota $\mathrm{n}^{\circ} 121$, p. 528; SIMS, Symptoms in the mind, cit. nota $\mathrm{n}^{\circ} 120$, pp. 76 y ss. Así las cosas, existirían diversos grados de alucinación.

123 SIMS, Symptoms in the mind, cit. nota $\mathrm{n}^{\circ} 120, \mathrm{p} .77$.

${ }^{124}$ En la inimputabilidad, nos podemos centrar en el grado de anormalidad de la percepción que puede observar el agente. Respecto de los fenómenos de anormalidad de la percepción, véase SIMS, Symptoms in
} 
estructura del acto existen diversas facetas que difieren de la percepción, como imaginar, recordar o abstraer. El agente puede imaginar algo que no existe, por ejemplo un unicornio. No obstante, puede estar imaginando un unicornio al ver un caballo, pero el acto perceptivo (caballo) y el imaginado (unicornio) son incompatibles, ya que mientras perciba el caballo, el agente sostiene su realidad y, mientras lo imagine, el unicornio continuará siendo irreal. Por ello, "esa es la razón por la cual las personas no apagan incendios reales con extintores imaginados". 125

La tesis enunciada deja intacta la estructura del error de prohibición en el miedo insuperable. En efecto, la enfermedad mental solo condiciona la percepción en el plano de la inimputabilidad, es decir, en casos de trastorno del juicio de la realidad. ${ }^{126}$ Sin embargo, en el miedo insuperable el trastorno no es privativo del juicio de la realidad porque se encuentra fuera del plano de la psicosis. Por ello, solo es posible una superposición entre el acto perceptivo e imaginario en el plano de la inimputabilidad. De ahí que considerar peligros imaginarios en el miedo insuperable no es adecuado, porque el trastorno en cuestión no tiene la entidad suficiente para condicionar el acto de percepción. Lo contrario, supondría validar una interpretación en la que el miedo solo responde a una cualidad inherente al sujeto ante un estímulo de una situación de peligro o agresión ilegítima. Es decir, una cualidad ajena a la valoración normativo-empírica en la que debemos determinar si el comportamiento responde a los parámetros del art. $10 \mathrm{~N}^{\circ} 9$.

Ahora bien, la situación de peligro en el miedo es aleatoria como en cualquier situación de estado de necesidad; sin embargo, esta aleatoriedad del peligro, sea de una fuente interna como externa, no trastorna el juicio de realidad del agente. El miedo alude a una

the mind, cit. nota $\mathrm{n}^{\circ} 120$, pp. 78 y ss. Por último, posiblemente las reglas del error de prohibición son más adecuadas para apreciar la conducta del agente frente a males irreales, en una situación de miedo insuperable, porque, pese a encontrarse bajo una perturbación anímica, el individuo puede percibir la realidad del mal, a diferencia de un inimputable. Por ello, es posible considerar las características patológicas del autor en el miedo insuperable, siempre y cuando se relacionen estas a la forma en que enfrenta el mal que pretende evitar. Por tanto, nos cuesta reservar el miedo insuperable al criterio de un hombre medio sin considerar las características patológicas que puede presentar el agente, MIR PUIG, Santiago, Derecho penal. Parte general, 9a ed., Barcelona: Reppertor, 2011, p. 610, § 25. En esta línea, se podría determinar -según las circunstancias del caso concreto- la subsistencia del dolo o la imprudencia (error vencible) o la exclusión de la culpabilidad (error invencible), HIGUERA, La eximente del miedo insuperable, cit. nota $\mathrm{n}^{\circ} 15$, $\mathrm{pp}$. 139151; CURY, "El estado de necesidad", cit. nota n 61, p. 265; CURY, Enrique, Derecho Penal, cit. nota ${ }^{\circ}$ 16, pp. 362-363; VAN WEEZEL, Álex, Error y mero desconocimiento en Derecho penal, Santiago: LegalPublishing, 2008, pp. 59-62; MIR, Derecho penal, cit. nota $n^{\circ} 124$, p. 612, § 29. De lo contrario, subjetivizaríamos en extremo el comportamiento del agente, dando una aplicación arbitraria al miedo insuperable. Ello, porque cualquier perturbación psicológica, no privativa de razón, eximiría de responsabilidad al agente. Consideraciones que se pueden desprender al reconocer la realidad del mal en el miedo insuperable y la imposibilidad de trasladar las posibles características patológicas del agente a un trastorno mental transitorio, MIR, Derecho penal, cit. nota $n^{\circ} 124$, p. 610, § 25. En contra, CÓRDOBA RODA, Juan y RODRÍGUEZ MOURULlO, Gonzalo, Comentarios al Código Penal, t. I, Barcelona: Editorial Ariel, 1972, p. 351.

${ }^{125}$ OJEDA, La tercera etapa, cit. nota $\mathrm{n}^{\circ} 5$, p. 61. El objeto imaginario solo es parte del agente y no puede ser percibido por un tercero externo, razón por la cual se le denomina autorreferente. Asimismo, en el caso del delirio, para el agente el acto imaginario no es imaginario. Por ello, para el agente la autorreferencia constituye una realidad que se define como delirio, véase OJEDA, La tercera etapa, cit. nota ${ }^{\circ}$ 5, pp. 62-65.

${ }^{126}$ Véase MARTÍNEZ, La imputabilidad penal, cit. nota ${ }^{\circ} 3$, pp. 415 - 419. 


\section{Polít. Crim. Vol. 14, № 28 (Diciembre 2019), Art. 2, pp. 54-94. [http://politcrim.com/wp-content/uploads/2019/10/Vol14N28A2.pdf]}

"experiencia intelectual del peligro, a la vertiente cognitiva del riesgo". ${ }^{127}$ En cambio, la angustia, como toda emoción, responde a respuestas vegetativas involuntarias que se traducen en sensaciones corporales y síntomas físicos como sudoración, temblor, taquicardia, etc. ${ }^{128}$ Por tanto, los agentes que se encuentran en un estado permanente de psicosis y los niños menores de catorce años solo podrían experimentar una angustia desligada del miedo. El miedo requiere de una capacidad superior de integración psíquica propia del adolescente o adulto, porque permite identificar riesgos actuales, potenciales o inminentes. En cambio, la angustia se relaciona con todo organismo vivo. Angustia que en un sentido puro solo pueden experimentar organismos de un estrato psíquico primitivo. ${ }^{129}$ El hombre en un estado primitivo debe su comportamiento a un impulso de preservación. Impulso que se reconoce bajo el rótulo de instinto de conservación. Sin embargo, este no es un mero reflejo por los complejos factores neurológicos y psíquicos que envuelve. Por ello, se utiliza el término emoción para hablar de los factores que conllevan una reacción en el agente, en el cual se inserta el miedo, entre otros. ${ }^{130}$

Esta distinción entre la angustia y el miedo nos permite apreciar este último como "una experiencia más intelectual que emocional", ${ }^{131}$ pues supone la existencia de una capacidad

${ }^{127}$ PEÑA Y LILLO, La angustia: Antropología y Clínica, cit. nota $\mathrm{n}^{\circ}$ 115, p. 95.

${ }^{128}$ PEÑA Y LILLO, El temor y la felicidad, cit. nota $n^{\circ} 68$, pp. 66-67.

${ }^{129}$ PEÑA Y LILLO, La angustia: Antropología y Clínica, cit. nota $\mathrm{n}^{\circ} 115$, p. 96 . Este razonamiento tiene relación en la dogmática con el discernimiento que tienen los adolescentes en nuestro sistema jurídico penal, en consideración de los arts. 2 y 3 de la Ley 20.084. Disposiciones que protegen el interés superior del adolescente (art. 2) y los límites en la responsabilidad penal juvenil que comprende el tramo que va de los 14 a 18 años de edad (art. 3). El Mensaje define a los adolescentes como personas mayores de 14 años y menores de 18. Con esta definición sigue "la tendencia del derecho comparado y de la doctrina, renunciando el Estado a toda acción coactiva en el caso de la comisión de delitos por personas de menos de 14 años, en concordancia con las disposiciones de la Convención Internacional de los Derechos del Niño", PRIMER INFORME DE COMISIÓN DE CONSTITUCIÓN, Historia de la Ley $N^{o} 20.084$. Establece un sistema de responsabilidad de los adolescentes por infracciones a la ley penal, 2005, p. 45, en: https://www.bcn.cl/historiadelaley/nc/historia-de-la-ley/5762/ [visitado el 03.05.2018]. En contra de esta posición, la Neurociencia, en la actualidad, ha comprobado que el cerebro continúa su evolución hasta los 21 años, donde las regiones frontales maduran en la última etapa. Estas regiones frontales son fundamentales en la toma de decisiones, por ello una persona de 17 años no tiene absolutamente desarrollada esta región cerebral, lo que dificulta el control de los impulsos, POZO SILVA, Nelson, Imputabilidad penal y mente, cit. nota $\mathrm{n}^{\circ} 110$, pp. 53-54.

${ }^{130}$ En esta línea, véase MIRA Y LÓPEZ, Emilio, Cuatro gigantes del alma: el miedo, la ira, el amor, el deber, 14 ed., Buenos Aires: Lidiun, 1994, p. 10. La posición de este autor no conlleva una distinción entre la angustia y el miedo; por el contrario, realiza una propuesta de interpretación que no es capaz de diferenciar cuáles serían las características esenciales del miedo. El problema de este razonamiento es que vincula en exceso el comportamiento instintivo en el hombre con su capacidad reflexiva.

${ }^{131}$ PEÑA Y LILLO, La angustia: Antropología y Clínica, cit. nota ${ }^{\circ} 115$, p. 96 . Así pues, esta diferenciación entre el miedo y la angustia no se presenta de forma tan tajante en la filosofía alemana después de la Primera Guerra Mundial. En este contexto, "en los años veinte tras la Gran Guerra [se] impulsó como valor una cierta mística de la muerte - piénsese por ejemplo en el «ser para la muerte» que Heidegger pregonaba por aquellos años- como medio de superación de la angustia vital", HERNÁNDEZ-PACHECO, Javier, El duelo de Athenea. Reflexiones filosóficas sobre guerra, milicia y humanismo, Madrid: Ediciones Encuentro, 2008, p. 59. Planteamiento en el cual "donde, por cierto, «angustia» es una regular traducción del alemán Angst, que significa también «miedo»", HERNÁNDEZ-PACHECO, El duelo, cit. nota n ${ }^{\circ} 131$, p. 59. No obstante, esta indiferenciación entre el miedo y la angustia genera problemas en la dogmática penal para poder identificar la esencia del miedo insuperable. Ello, debido a que incorporaría elementos de la angustia, atingentes a síntomas físicos o sensaciones puramente corporales, en el miedo insuperable. 
en el agente que le permite identificar a lo menos la potencialidad de una situación de peligro o agresión ilegítima. Capacidad que no se reduce a una mera reacción biológica. ${ }^{132}$ Si bien existe un margen de libertad en la elección que se puede reducir a una sola opción, esto no implica una restricción total de su libertad. En el miedo el agente tiene la capacidad intelectual de representarse la potencialidad o inminencia del peligro. El miedo supone una mirada crítica de la realidad que conlleva la capacidad de percibirla. Lo último, pese a que el agente sufra una perturbación o trastorno del sentido de la realidad que afecte su elección al momento de enfrentar la situación de peligro o la agresión.

\subsection{Trastorno del sentido de la realidad en el miedo insuperable}

El elemento subjetivo que se observa en el miedo insuperable es un trastorno del sentido de la realidad, porque no impide al agente diferenciar entre acto perceptivo e imaginario. En otras palabras, estamos en presencia de un trastorno mental que es producto de una anomalía psíquica en la cual el sujeto puede distinguir lo real de lo irreal, con independencia de la posibilidad de errar en la apreciación de los hechos. Ello porque la reacción del agente responde a la presencia de un impulso irresistible sistemático que se presenta con lucidez de conciencia. ${ }^{133}$ En consecuencia, si bien el miedo insuperable se presenta en la dogmática chilena relacionado con una perturbación anímica que puede ser reflejo de un mal real o imaginario, nos parece que el miedo insuperable solo responde ante la presencia de un mal real; de lo contrario, se generaría una descompensación importante con otras eximentes e instituciones jurídicas, como podemos observar en la jurisprudencia.

Así las cosas, la sentencia de la Corte de Apelaciones de Santiago, contra Olga Torrealba Cornejo, del 10 de septiembre de 1958, aceptó la posibilidad de incorporar una falsa apreciación de las circunstancias del peligro, como en la legítima defensa y otras circunstancias, en el miedo insuperable. En el caso en cuestión la acusada es absuelta porque obró a causa de un temor patológico que la privó de razón. La Corte consideró que "así como en la legítima defensa y en otras circunstancias, puede producirse en el actor una falsa apreciación de las circunstancias y detalles de los hechos en los cuales aparece como presunta víctima, ese error de hecho o falsa apreciación del peligro por producirse, o la simple o falsa apreciación del peligro por producirse, o la simple amenaza de ellos, no hace desestimable su explicación [y] no hace rechazable por ende sus excusas".

Para la Corte de Apelaciones de Santiago, la eximente resulta igualmente aplicable aun "cuando [la acusada] no hubiera estado ante la inminencia real de un ataque, castigo o

\footnotetext{
${ }^{132}$ En este contexto, generalmente la confusión entre miedo y ansiedad proviene de su indiferenciación en la neurociencia y la psiquiatría. Para evitar tal confusión, algunos en el campo de la neurociencia correlacionan el miedo con un estado mental ante un daño o amenaza inmediata o inminente. En cambio, la ansiedad se vincula con sentimientos propios de la incertidumbre del daño en un sentido espacio temporal. Con todo, si bien se puede observar en los animales y en los humanos que la amígdala es un área del cerebro que controla el comportamiento y las respuestas fisiológicas ante las amenazas, ello no significa que la experiencia del miedo provenga de un área del cerebro en particular. Pues bien, pacientes con la amígdala dañada pueden seguir sintiendo miedo, dolor e incluso pánico, véase LEDOUX, Joseph E. y PINE, Daniel S., "Using Neuroscience to Help Understand Fear and Anxiety: A Two-System Framework", Am J Psychiatry 173:11 (2016), pp. 1083 - 1093, pp. 1084 - 1085.

${ }^{133}$ MAZZARELLI, Lecciones de psicología anormal, cit. nota $\mathrm{n}^{\circ} 49$, pp. 182-183.
} 


\section{Polít. Crim. Vol. 14, № 28 (Diciembre 2019), Art. 2, pp. 54-94. [http://politcrim.com/wp-content/uploads/2019/10/Vol14N28A2.pdf]}

posible daño $[\ldots]{ }^{134}$ En el caso, la acusada Olga Torrealba, víctima de innumerables maltratos físicos y psicológicos, decidió anteponerse al hecho de que su marido la matara. Por ello, Olga tomó primero que su marido la pistola cargada que este trató de sacar del cajón de su velador con el propósito de matarla. Sin embargo, la problemática nos parece que debió centrarse en el error de prohibición. Pues bien, si estamos frente a un mal imaginario producto de la equivocada interpretación de un fenómeno que acontece en la realidad, debemos dirigirnos a esta última institución. Así pues, frente a un mal imaginario, aunque el agente padezca de un trastorno del sentido de la realidad, procede remitirnos al error de prohibición y determinar la vencibilidad o invencibilidad de la representación. Este enfoque hace irrelevante el argumento de aquella doctrina que sustenta tratar el mal imaginario en el miedo insuperable, ya que su producción no incide en un trastorno del juicio de la realidad que explique su impunidad (inimputabilidad). Esto implica hacer del miedo insuperable una eximente que solo presenta compatibilidad con la existencia de un mal real que provoque en el agente la perturbación de conciencia con el objeto de diferenciarla de la inimputabilidad. ${ }^{135}$

En este orden de ideas, postulamos que los trastornos mentales que pueden comprender ambas eximentes (miedo insuperable e imputabilidad disminuida) son equivalentemente graves, al igual que en el arrebato y obcecación, únicamente respecto de los casos de imputabilidad disminuida, en el caso de un trastorno de apreciación de la realidad frente a la ausencia objetiva o real de un estímulo ilícito o ilícito. Cabe destacar que la sentencia de la Corte Suprema, contra Julia Hevia contra José Víctor y Manuel Jesús Montenegro Beiza, Rol 17.788, estableció que:

"se ha admitido por la doctrina que en los casos de semi-alienación, estados crepusculares o privación parcial de razón pueda admitirse esta atenuante [art. $11 \mathrm{~N}^{\circ}$ 1 en relación con el art. $10 \mathrm{~N}^{\circ} 1$ ], porque en realidad entre la salud mental normal y la perturbación psíquica absoluta existen grados o trastornos mentales incompletos que producen imputabilidad disminuida". ${ }^{136}$

Grados de perturbación que se observan en el miedo insuperable y que han llevado en más de una ocasión -como se puede observar en la jurisprudencia- a confundir el miedo insuperable con la inimputabilidad. ${ }^{137}$ Más en concreto, los grados de perturbación de conciencia deben venir acompañados en el miedo insuperable de un requisito indiferente a la imputabilidad disminuida: la realidad del mal. Si el miedo insuperable tuviera una

\footnotetext{
${ }^{134}$ Sentencia de la Corte de Apelaciones de Santiago, 10 de septiembre de 1958, RDJ, t. XV, secc. cuarta, p. 147.

${ }^{135}$ En este sentido, alucinaciones que provengan de la sugestión personal o cultural son alucinaciones falsas que no son parte del grupo de alucinaciones delirantes, EY, Henri, Tratado de psiquiatría, $8^{\text {a }}$ ed., Barcelona: Toray-Masson, 1978, p. 105. Las alucinaciones delirantes son las que interesan en el campo de la inimputabilidad. Ello no implica negar la posibilidad de considerar aquellas alucinaciones falsas o propias de ilusiones normales del agente en el campo del error de prohibición.

${ }^{136}$ Sentencia de la Corte Suprema, Rol 17.788, FM, año XIII, 23 agosto de 1971, № 153, considerando séptimo, letra a), p. 189.

${ }^{137}$ Sentencia de la Corte de Apelaciones de Santiago, 10 de septiembre de 1958, RDJ, t. LV, septiembre y octubre, N.os 7 y 8, segunda parte, secc. cuarta, pp. 147-153; Sentencia de la Corte Suprema, 25 de abril de $1955, R D J$, t. LII, enero y abril, N.os 1 y 2 , segunda parte, secc. cuarta, pp. 211-255, entre otras.
} 
entidad normativa equivalente a la imputabilidad disminuida, alusiva únicamente a la entidad de la perturbación, no sería posible, lógicamente, contemplar una eximente incompleta del miedo, porque entraría en colisión con la imputabilidad disminuida al cumplir exactamente la misma función.

En definitiva, puede observarse como dogmática y jurisprudencialmente existe un reconocimiento en la graduación de los trastornos mentales. Así pues, se requiere de un criterio normativo que nos permita su graduación, de forma tal que una vez realizado el diagnóstico del trastorno mental el juez considere ese resultado y lo compare "con un estándar de diferenciación que se supone vigente en una sociedad y en un momento dado, y [decida] si la desviación de la normalidad es suficiente como para determinar la apreciación de la imputabilidad o de imputabilidad disminuida"138 e incluso la presencia del miedo insuperable. Es decir, que "se reserva al juez libertad para apreciar posteriormente si ese dato reviste la suficiente gravedad desde el punto de vista de la responsabilidad penal". ${ }^{139}$

Fenómeno de graduación de los trastornos mentales que también se presentaría entre el miedo insuperable y la atenuante de arrebato y obcecación, exigiendo la existencia de un mal real en el miedo insuperable, si la entidad de la perturbación fuera menor a la de un trastorno del sentido de la realidad. Lo último, debido a que si la perturbación de ánimo es leve (trastorno de apreciación de la realidad), se entrelazaría con una eximente incompleta de miedo insuperable que requeriría, al igual que el arrebato u obcecación, de un estímulo objetivo. Por ello, concordamos con el planteamiento de que "los requisitos que exige la eximente del $\mathrm{N}^{\circ} 9^{\circ}$ del artículo 10 del citado Código tienen un carácter absoluto que no admite graduación y por lo mismo, no puede darse su concurrencia incompleta", ${ }^{140}$ según lo dispuesto en la sentencia de la Corte de Apelaciones de Santiago, contra González Díaz, Miguel Abraham, del 8 de junio de 1963. Pues bien, consideramos que no es posible la existencia de una eximente incompleta de miedo insuperable. En esta línea, respecto de la perturbación de ánimo del arrebato y obcecación, nos parece que cuando ella tiene una mayor entidad o duración puede ir desde un trastorno del sentido de la realidad (miedo insuperable o imputabilidad disminuida) a un trastorno del juicio de la realidad, "cuando ya tiene mayor duración y constituye una anormalidad mental se transforma en un trastorno mental transitorio [(inimputabilidad)]". ${ }^{141}$

Con todo, la valoración de la función objetiva y de significado no radica en un parámetro sociocultural objetivo, porque - aunque ello fuera posible- las convicciones sociales pueden llegar a ser directamente irracionales. Por ello, si bien el sustrato psicopatológico acompañar la realización de la acción, la ausencia de culpabilidad radica en un "mandato de igualdad real derivado de los principios constitucionales: al no alcanzar la decisión tomada el grado suficiente de diferenciación estructural", ${ }^{142}$ y no en la falta de autodeterminación.

\footnotetext{
${ }^{138}$ MARTÍNEZ, La imputabilidad penal, cit. nota ${ }^{\circ}$ 3, p. 260.

${ }^{139}$ MARTÍNEZ, La imputabilidad penal, cit. nota ${ }^{\circ}$ 3, p. 260.

${ }^{140}$ Sentencia de la Corte de Apelaciones de Santiago, 8 de junio de 1963, RDJ, t. LX, mayo y junio, N.os 3 y 4, segunda parte, secc. cuarta, considerando séptimo, p. 268.

${ }^{141}$ Sentencia de la Corte Suprema, 28 de marzo de 1972, FM, marzo, 1972, N $^{\circ}$ 160, año XIV, considerando quinto, pp. 22-23.

${ }^{142}$ MARTÍNEZ, La imputabilidad penal, cit. nota $\mathrm{n}^{\circ}$ 3, p. 263.
} 


\section{Balance y conclusiones}

El adecuado análisis del impulso irresistible exige combinar elementos normativos y empíricos para superar la falta de conceptualización en la graduación de los trastornos mentales. Si se atiende a las normas del miedo insuperable, la inimputabilidad y la atenuante de arrebato y obcecación, en el sistema jurídico-penal chileno, emerge una pretensión adicional, consistente en entregar un parámetro que sea confiable en la materia. Pues bien, el reconocimiento del impulso irresistible, nos conduce a comprender que conviven en el Derecho penal una pretensión normativa y empírica en torno a un mismo objetivo: la incidencia de la gravedad del trastorno en la exigibilidad de otra conducta. En síntesis, se trata de dos pretensiones que buscan encontrar un parámetro normativo para establecer un punto de referencia en el plano de valoración jurídico-penal.

A pesar de la existencia de un sector de la doctrina que afirma la posibilidad de aceptar males imaginarios en el miedo insuperable, no faltan autores en la doctrina que defienden la vinculación del miedo insuperable con males reales, sea como forma de agresión ilegítima, sea como peligro actual o inminente en hipótesis de estado de necesidad. Dichos autores pretenden materializar en el miedo situaciones más bien atingentes a un estado de necesidad exculpante, aunque las propuestas que se observan en la doctrina chilena responden a la existencia de trastornos mentales que explican la falta de proporcionalidad o subsidiariedad en el estado de necesidad o la legítima defensa.

Nos parece, sin embargo, que las interpretaciones enunciadas tienen algunos límites: en primer lugar, el peligro imaginario no está al alcance del miedo insuperable. A fin de cuentas, ésta eximente reconoce supuestos de hechos que pueden responder tanto a la legítima defensa como el estado de necesidad en los que la perturbación explica la falta de subsidiariedad o proporcionalidad. Así, al no delimitar el legislador el miedo insuperable a una agresión ilegitima o situación de peligro, el foco de la interpretación se encuentra en el impulso irresistible. De ahí que entren en juego otros factores empírico-normativos que no están vinculados a males imaginarios, sino a males reales que provocan en el agente un trastorno del sentido de la realidad. Trastorno mental que permite al agente diferenciar entre acto perceptivo e imaginario. En definitiva, por tanto, puede afirmarse que un mal imaginario en el miedo insuperable responde a los parámetros del error de prohibición. 


\section{Bibliografía}

ALONSO ARIAS P., Antonio, El miedo insuperable y la fuerza o violencia moral e irresistible, Santiago: Ediar Conosur, 1985.

ANTÓN ONECA, José, Derecho penal, 2ª ed., Madrid: Akal, 1986.

BARBERO, Natalia; SALDUNA, Mariana, "Responsabilidad penal del psicópata", Revista Latinoamericana de Derecho, año IV, n 7-8 (2007), pp. 89 - 127.

BERRÍOS, Germán E., Historia de los síntomas de los trastornos mentales: la psicopatología descriptiva desde el siglo XIX, México, D.F.: Fondo de Cultura Económica, 2008.

BLEULER, Eugen, Demencia precoz. El grupo de las esquizofrenias, Buenos Aires: Editorial Paidós, 1960.

BULlEMORE, Vivian; MACKINNON, John, Curso de Derecho Penal, Teoría del delito, t. II, $2^{\mathrm{a}}$ ed., Santiago: LexisNexis, 2007.

BLUGGER S.I., Walter, Diccionario de Filosofía, Barcelona: Editorial Erder, 1975.

CABIESES, Ricardo, Derecho penal: Apuntes tomados en clase correjidos $i$ aumentados por R. B. P. i P. G. G., Santiago: Editorial Universitaria, 1915.

CAPPONI M., Ricardo, Psicopatología y semiología psiquiátrica, 12ª ed., Santiago: Universitaria, 2011.

CEREZO MIR, José, Curso de Derecho penal español. Parte general, t. III, Madrid: Tecnos, 2001.

COMISIÓN REDACTORA DEL CÓDIGO PENAL CHILENO, Código Penal de la República de Chile y Actas de las sesiones de la Comisión Redactora, con un estudio preliminar de Manuel de Rivacoba y Rivacoba, Valparaíso: Edeval, 1974.

CORCOY BIDASOLO, Mirentxu y MIR PUIG, Santiago, Comentarios al Código Penal. Reforma LO 5/2010, Valencia: Tirant lo Blanch, 2011.

CÓRDOBA RODA, Juan y RODRÍGUEZ MOURULLO, Gonzalo, Comentarios al Código Penal, t. I, Barcelona: Ariel, 1972.

COUSIÑO MAC IVER, Luis, Derecho penal chileno. Parte general, t. I, Santiago: Jurídica de Chile, 1979.

CUERDA ARNAU, María Luisa, El miedo insuperable. Su delimitación frente al estado de necesidad, Valencia: Tirant lo Blanch, 1997.

CURY, Enrique, Derecho Penal. Parte General, $7^{\mathrm{a}}$ ed., Santiago: Ediciones Universidad Católica de Chile, 2005.

CURY, Enrique, "El estado de necesidad en el Código Penal Chileno", en: MAÑALICH, Juan Pablo (Coord.), La Ciencia Penal en la Universidad de Chile. Libro homenaje a los profesores del Departamento de Ciencias Penales de la Facultad de Derecho de la Universidad de Chile, Santiago: Universidad de Chile, 2013.

ENGISCH, Karl, La teoría de la libertad de la voluntad en la actual doctrina filosófica del Derecho penal, Trad.: José Luis Guzmán Dalbora, Valparaíso: Edeval, 2006.

ETCHEBERRY ORTHUSTEGUY, Alfredo, El Derecho penal en la jurisprudencia, t. II. Parte General, Concepción: S. Muñoz Vera, 1971.

ETCHEBERRY ORTHUSTEGUY, Alfredo, Derecho Penal, t. I, $3^{\text {a }}$ ed., Santiago: Jurídica de Chile, 1998.

ETCHEBERRY ORTHUSTEGUY, Alfredo, Derecho Penal, t. II, $3^{\text {a }}$ ed., Santiago: Jurídica de Chile, 1998.

EY, Henri, Tratado de psiquiatría, 8ª ed., Barcelona: Toray-Masson, 1978. 
FEINBERG, Joel, "What Is So Special about Mental Illness?", Doing and Deserving, Princeton: Princeton University Press, 1970.

FEINBERG, Joel, "Harm to Self", The moral limits of the criminal law, vol. 3, Oxford: Oxford University Press, 1984.

FERNÁNDEZ, Pedro Javier, Código Penal de la República de Chile. Esplicado $i$ Concordado, $2^{\mathrm{a}}$ ed., Santiago: Imprenta, litografía i Encuadernación Barcelona, 1899.

FIANDACA, Giovanni; MUSCO, Enzo, Derecho penal. Parte general, Trad.: NIÑO, Luis Fernando, Bogotá: Temis, 2006.

FIGUEIREDO DIAS, Jorge de, Liberdade - culpa - direitto penal, Portugal: Coimbra, 1976.

FONSECA MORALES, Gema María, La anomalía o alteración psíquica como eximente o atenuante de la responsabilidad criminal, Madrid: Dykinson, 2009.

FRANKFURT, Harry, Demonds, Dreamers and Madmen: The Defense of Reason in Descartes`s Meditations, Princeton: Princeton University Press, 2007.

FRISTER, Helmut, Die Struktur des "voluntativen Schuldelements": Zugleich eine Analyse des Verhältnisses von Schuld und positiver Generalprävention, Berlin: Duncker \& Humbolt, 1993.

FUENSALIDA, Alejandro, Código Penal Chileno, t. I, Lima: Imp. Comercial Calle del Huallacan $\mathrm{n}^{\circ} 139,1883$.

FULFORD, K.W.M., "Value, Action, Mental Illnes and the Law", en: SHUTE, Stephen (Ed.), Action and value in criminal law, Oxford: Clarendon Press, 1996.

GARCÍA-BARÓ, Miguel, Fenomenología y hermenéutica, España: Editorial Bonallertra Alcompas, 2015.

GARCÍA PABLOS DE MOLINA, Antonio, Introducción al Derecho Penal: Instituciones, fundamentos y tendencias del Derecho Penal, Madrid: Editorial Universitaria Ramón Areces, 2012.

GARCÍA SOTO, María Paulina, El estado de necesidad en materia penal, Santiago: Jurídica ConoSur, 1999.

GARRIDO MONTT, Mario, Derecho Penal. Parte general, t. I, $4^{\mathrm{a}}$ ed., Santiago: Jurídica de Chile, 2007.

GHIRARDI, Olsen A., Lecciones de lógica del Derecho, Córdoba: Universidad Nacional, 1982.

GUERRA ESPINOSA, Rodrigo, Estado de necesidad como conflicto de intereses: una interpretación: una propuesta de interpretación desde la inevitabilidad, Santiago (Chile): Ara Editores, 2017 pp. 21 - 218.

HERNÁNDEZ BASUALTO, Héctor, "Comentario al art. $10 \mathrm{~N}^{\mathrm{o}} 1$ del Código Penal", en: COUSO SALAS, Jaime; HERNÁNDEZ BASUALTO, Héctor (Dirs.), Código Penal Comentado. Parte General. Doctrina y jurisprudencia, Santiago: AbeledoPerrot-LegalPublishing, 2011.

HERNÁNDEZ BASUALTO, Héctor, “Comentario al art. 10 № 9 del Código Penal”, en: COUSO SALAS, Jaime; HERNÁNDEZ BASUALTO, Héctor (Dirs.), Código Penal Comentado. Parte General. Doctrina y jurisprudencia, Santiago: AbeledoPerrot-LegalPublishing, 2011.

HERNÁNDEZ-PACHECO, Javier, El duelo de Athenea. Reflexiones filosóficas sobre guerra, milicia y humanismo, Madrid: Ediciones Encuentro, 2008. 
HIGUERA GUIMERÁ, Juan Felipe, La eximente del miedo insuperable en el derecho penal común y militar español, Barcelona: Bosch, 1991.

HUSSERL, Edmund, Ideas relativas a una fenomenología pura y una filosofía fenomenológica, Trad.: GAOS, José, México, D.F.: Fondo de Cultura Económica, 1962.

HUSSERL, Edmund, Investigaciones lógicas, Madrid: Biblioteca Revista de Occidente, 1976.

INSTITUTO DE CIENCIAS PENALES, Proyecto de Código Penal Tipo para Iberoamérica. Antecedentes, plan de trabajo, documentos preparatorios, Santiago: Universitaria, 1963.

JAKOBS, Günther, Sobre la normativización de la dogmática jurídico-penal, Trad.: CANCIO MELIÁ, Manuel;| FEIJÓO SÁNCHEZ, Bernardo, Madrid: ThomsonCivitas, 2003.

JASPERS, Karl, Psicopatología general, Trad.: SAUBIDET, Roberto O; SANTILLÁN, Diego A., $2^{a}$ ed., México, D.F.: Fondo de Cultura Económica, 1993.

JIMÉNEZ DE ASÚA, Luis, Tratado de Derecho penal, t. I, 4 ed., Buenos Aires: Editorial Losada, 1964.

JIMÉNEZ DÍAZ, María José; FONSECA MORALES, Gema María, Trastornos de la personalidad (psicopatías). Tratamiento científico y jurisprudencial, $2^{\mathrm{a}}$ ed., Madrid: CESEJ-Ediciones, 2007.

JOSHI JUBERT, Ujala, Anomalía y alteración psíquica en el Código Penal español, Madrid: Grupo Difusión Jurídica, 2009.

KERNBERG, Otto, Internal world and external reality, New York: J. Aronson, 1985.

KIERKEGAARD, Sören, El concepto de la angustia, Madrid: Alianza Editorial, 2007.

LABATUT GLENA, Gustavo, Derecho Penal. Parte General, 9a ed., Santiago: Jurídica de Chile, 2005.

LARENZ, Karl, Metodología de la Ciencia del Derecho, Trad.: RODRÍGUEZ MOLINERO, Marcelino, 2a ed., Barcelona: Editorial Ariel, 1980.

LEDOUX, Joseph E.; PINE, Daniel S., "Using Neuroscience to Help Understand Fear and Anxiety: A Two-System Framework", Am J Psychiatry 173:11 (2016), pp. 1083 1093.

LÓPEZ DÍAZ, Claudia, Código Penal alemán: del 15 de mayo de 1871, con la última reforma del 31 de enero de 1998, Bogotá: Universidad Externado de Colombia, 1999.

LUTHE, Rainer, «Schuldfähigkeit-ein rationales Mittel sozialer Regulation?», SchwZStr 103 (1986), pp. 345 -366.

MAÑALICH, Juan Pablo, "El estado de necesidad exculpante. Una propuesta de interpretación del artículo $10 \mathrm{~N}^{\circ} 11$ del Código Penal Chileno", en: VAN WEEZEL, Alex (Ed.), Humanizar y renovar el Derecho penal. Estudios en memoria de Enrique Cury, Santiago: LegalPublishing, 2013.

MAÑALICH, Juan Pablo, "La imprudencia como estructura de imputación”, Revista de Ciencias Penales, vol. XLII, $\mathrm{n}^{\circ} 3$ (2015), pp. 13-35.

MAÑALICH, Juan Pablo, “¿Arrebato y obcecación pasionalmente condicionados como atenuante por un femicidio frustrado?", Revista de Estudios de la Justicia, n 25 (2016), pp. $245-258$.

MAÑALICH, Juan Pablo, "Miedo insuperable y obediencia jerárquica", Revista de Derecho, vol. XXI, no 1 (2008), pp. $61-73$. 
MAÑALICH, Juan Pablo, "Informe en Derecho: Error de tipo y error de prohibición en los delitos contra la autodeterminación sexual", Departamento de Estudios de la Defensoría Penal Pública, $\mathrm{n}^{\circ} 2$ (2011), pp. 1 - 48.

MARCONI, Juan, "El delirio y sus estructuras psicopatológicas", Rev Chil Neuropsiquiatría 38 (2000), pp. 37-43.

MARTÍNEZ GARAY, Lucía, La imputabilidad penal: concepto, fundamento, naturaleza jurídica y elementos, Valencia: Tirant lo Blanch, 2005.

MATUS ACUÑA, Jean Pierre, "Fernández, Fuenzalida y Vera: Comentaristas, autodidactas y olvidados. Análisis diacrónico y sincrónico de la doctrina penal chilena del siglo XIX”, Revista Ius et Praxis, vol. 12, n 1 (2006), pp. 31 - 67.

MATUS ACUÑA, Jean Pierre (2010): "La doctrina penal de la (fallida) recodificación chilena del Siglo XX y principios del XXI", Revista Política Criminal, vol. 5, no 9 (2010), pp. 143 - 206.

MAZZARELLI, Alfonso, Lecciones de psicología anormal y patológica, Santiago: Universidad Diego Portales, 2006.

MELENDO PRADOS, Miguel, El concepto material de culpabilidad y el principio de inexigibilidad, Granada: Editorial Comares, 2000.

MERA, Jorge, "Comentario al art. $11 \mathrm{~N}^{\circ} 5$ del Código Penal", en: COUSO SALAS, Jaime; HERNÁNDEZ BASUALTO, Héctor (Dirs.), Código Penal Comentado. Parte General. Doctrina y jurisprudencia, Santiago: AbeledoPerrot-LegalPublishing, 2011.

MEZGER, Edmund, Derecho penal. Parte general, Trad.: FINZI, Conrado A.; NÚÑEZ C., Ricardo C., 6 ${ }^{a}$ ed., Buenos Aires: Editorial Bibliográfica Argentina, 1955.

MIR PUIG, Santiago, Derecho penal. Parte general, 9a ed., Barcelona: Reppertor, 2011.

MIRA Y LÓPEZ, Emilio, Cuatro gigantes del alma: el miedo, la ira, el amor, el deber, $14^{\mathrm{a}}$ ed., Buenos Aires: Lidiun, 1994.

MOORE, Michael S., Law and Psychiatry. Rethinking the relationship, New York: Cambridge University Press, 1984.

NÁQUIRA, Jaime, Derecho Penal. Teoría del Delito I, Santiago: Editorial McGrawHill, 1998.

NOVOA MONREAL, Eduardo, Curso de Derecho Penal chileno. Parte General, t. I, $3^{\mathrm{a}}$ ed., Santiago: Jurídica de Chile, 2005.

NOVOA MONREAL, Eduardo, Curso de Derecho Penal chileno. Parte General, $t$. II, $3^{\mathrm{a}}$ ed., Santiago: Jurídica de Chile, 2005.

OJEDA, César, La tercera etapa: Ensayos críticos sobre psiquiatría contemporánea, Santiago: Cuatro Vientos, 2003.

ORTIZ QUIROGA, Luis y ARÉVALO CUNICH, Javier, Las consecuencias jurídicas del delito, Santiago: Jurídica de Chile, 2013.

PACHECO, Joaquín Francisco, El Código Penal concordado y comentado, Madrid: Imprenta de la Viuda de Perinat y Compañía, 1888.

PAVEZ DIEZ, Mauricio, Trastornos mentales e imputabilidad, $2^{\mathrm{a}}$ ed., Santiago: Editorial Metropolitana, 2014.

PEÑA Y LILLO, Sergio, La angustia: Antropología y Clínica, Santiago: Editorial Universitaria, 1981.

PEÑA Y LILLO, Sergio, El temor y la felicidad, Santiago: Editorial Universitaria, 1989. 
PIÑA ROCHEFORT, Juan Ignacio, "Conocimiento y Sistema cognitivos. Algunas alteraciones sobre la imprudencia", Revista de Ciencias Penales, Sexta ÉPOCA, vol. XLII, $\mathrm{n}^{\circ} 3$ (2015), pp. $37-60$.

POLITOFF LIFSCHITZ, Sergio, et al., Lecciones de Derecho Penal. Parte General, $t .1,2^{\mathrm{a}}$ ed., Santiago: Editorial Jurídica de Chile, 2003.

POLITOFF LIFSCHITZ, Sergio y ORTIZ QUIROGA, Luis, Texto y comentario del Código Penal Chileno. t. I, Santiago: Jurídica de Chile, 2002.

POZO SILVA, Nelson, Imputabilidad penal y mente, Santiago: ARCIS, 2010.

PRAMBS JULIÁN, Claudio, El tipo de culpabilidad en el Código Penal Chileno. Una visión sistemática Normativa y Positiva, Santiago: Editorial Metropolitana, 2005.

PRIMER INFORME DE COMISIÓN DE CONSTITUCIÓN, Historia de la Ley $N^{o} 20.084$. Establece un sistema de responsabilidad de los adolescentes por infracciones a la ley penal, 2005, en: https://www.bcn.cl/historiadelaley/nc/historia-de-la-ley/5762/ [visitado el 03.05.2018]

QUINTANO RIPOLLÉS, Antonio, Comentarios al Código Penal, vol. I, Madrid: Revista de Derecho Privado, 1946.

QUINTERO OLIVARES, Gonzalo, Parte General del Derecho Penal, $4^{\mathrm{a}}$ ed., Barcelona: Thomson Reuters-Aranzadi, 2010.

RAGUÉS I VALLÈS, Ramón, “Consideraciones sobre la prueba del dolo", Revista de Estudios de la Justicia, No 4, 2004, pp. 13 - 26.

RASCH, Wilfried, Forensische Psychiatrie, 2a ed. revisada y ampliada, Stuttgart: Kohlhammer, 1999.

RIVACOBA Y RIVACOBA, Manuel, "Estudio preliminar", en Código Penal de la República de Chile. Actas de las sesiones de la comisión redactora, Valparaíso: Edeval, 1974.

RODRÍGUEZ, Darío y TORRES, Javier, “Autopiesis, la unidad de una diferencia: Luhmann y Maturana”, Sociologías, Porto Alegre, año 5, n9 (2003), pp. 106 - 140, en: http://www.scielo.br/pdf/soc/n9/n9a05.pdf [visitado el 22.08.2017].

ROXIN, Claus, Derecho penal. Parte general, t. I., Trad.: LUZÓN PEÑA, Diego Manuel, et al., $2^{\text {a }}$ ed., Madrid: Civitas, 1997.

SCHNEIDER, Kurt, Las personalidades psicopáticas, $7^{\mathrm{a}}$ ed., Madrid: Ediciones Morata, 1974.

SÁNCHEZ-OSTIZ, Pablo e IÑIGO CORROZA, Elena, Delictum 2.0, $2^{\mathrm{a}}$ ed., Navarra: Thomson Reuters, 2014.

SÁNCHEZ-OSTIZ, Pablo, La libertad en el Derecho penal. Estudios sobre la doctrina de la imputación, Barcelona: Atelier, 2014.

SILVA SÁNCHEZ, Jesús María, Perspectivas sobre la política criminal moderna, Buenos Aires: Depalma, 1998.

SIMS, Andrew, Symptoms in the mind: an introduction to descriptive psychopathology, London: W.B. Saunders, 1995.

STRATENWERTH, Günter, El futuro del principio jurídico penal de culpabilidad, Madrid: Publicaciones del Instituto de Criminología de la Universidad Complutense de Madrid, 1980.

URRUELA MORA, Asier, Imputabilidad Penal y anomalía o alteración psíquica. La capacidad de culpabilidad Penal a la luz de los modernos avances en psiquiatría y genética, Bilbao-Granada: Comares, 2004. 
VAN WEEZEL, Alex, Error y mero desconocimiento en Derecho penal, Santiago: LegalPublishing, 2008.

VARONA GÓMEZ, Daniel, El miedo insuperable: una reconstrucción de la eximente desde una teoría de justicia. Estudios de Derecho penal dirigidos por Carlos María Romero Casabona, Granada: Editorial Comares, 1999.

VARONA GÓMEZ, Daniel, "El miedo insuperable y la ética del hormigueo: reflexiones sobre el papel de las eximentes fundadas en la inexigibilidad de otra conducta", Revista de Estudios de la Justicia, no 12 (2010), pp. 59 - 94.

VILLEGAS DÍAZ, Myrna, "Homicidio de la pareja en violencia intrafamiliar. Mujeres homicidas y exención de responsabilidad penal", Revista de Derecho, vol. XXIII, $\mathrm{n}^{\circ}$ 2 (2010), pp. 149 - 174.

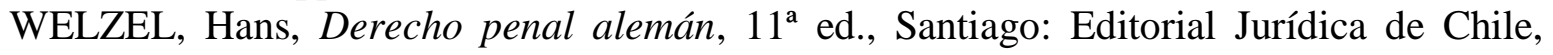
1970.

WELZEL, Hans, El nuevo sistema de Derecho penal. Una introducción a la doctrina de la acción finalista, Trad.: CEREZO MIR, José, Buenos Aires: Editorial B de F, 2004.

WILENMANN, Javier, "El fundamento del estado de necesidad justificante en el derecho penal chileno. Al mismo tiempo, introducción al problema de la dogmática del estado de necesidad en Chile", Revista de Derecho (Valdivia), vol. XXVII, nº 1 (2014), pp. $213-244$.

WILLIAM, James, The Principles of Psychology, $2^{\mathrm{a}}$ ed., Chicago: Encyclopaedia Britannica, Inc., 1990.

WITTE, Hermann, Unterschiedliche Perspektiven in der allgemeinen und in der forensischen Psychiatrie. Eine kleine Methodenlehre für Juristen, psychologischpsychiatrische Sachverständige und interessierte Laien, Berlin: Springer, 1990. 